THE COMEBACK QUEENS: UNDERSTANDING BLACK WOMEN'S TRANSITION FROM INCARCERATION TO HIGHER EDUCATION

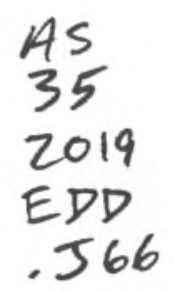

A Dissertation submitted to the faculty of San Francisco State University In partial fulfillment of the requirements for the Degree

Doctor of Education

In

Educational Leadership

by

Marilyn Denise Jones

San Francisco, California

May 2019 
Copyright by

Marilyn Denise Jones

2019 


\section{CERTIFICATION OF APPROVAL}

I certify that I have read The Comeback Queens: Understanding Black Women's Transition from Incarceration to Higher Education by Marilyn Denise Jones, and that in my opinion this work meets the criteria for approving a thesis submitted in partial fulfillment of the requirement for the degree Doctor of Education: Educational Leadership at San Francisco State University.
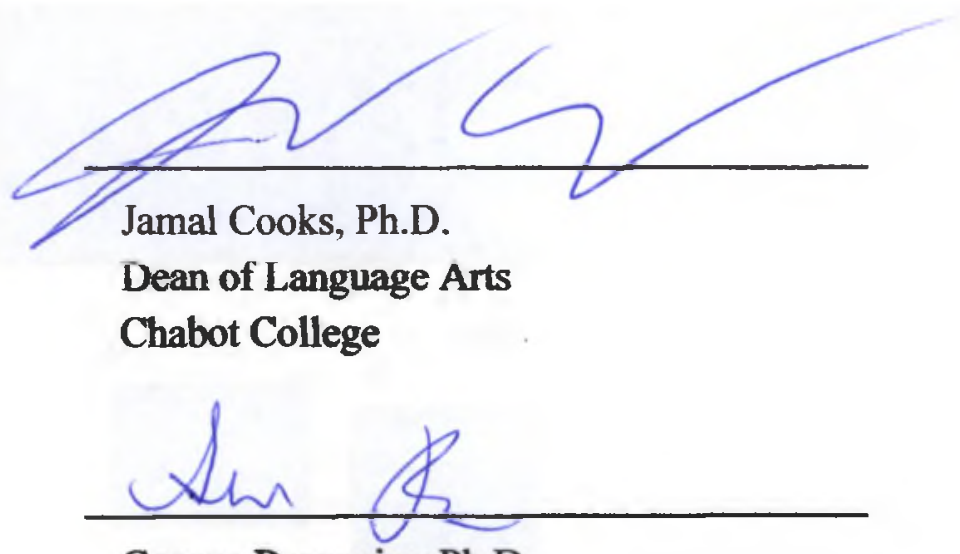

George Barganier, Ph.D.

Assistant Professor

San Francisco State Yniversity

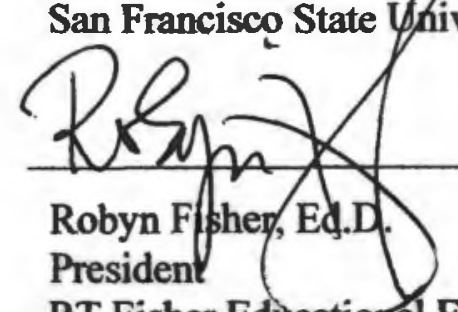

RT Fisher Edueational Enterprises 


\title{
THE COMEBACK QUEENS: UNDERSTANDING BLACK WOMEN'S TRANSITION FROM INCARCERATION TO HIGHER EDUCATION
}

\author{
Marilyn Denise Jones \\ San Francisco, California \\ 2019
}

To identify the social/emotional and academic characteristics of formerly incarcerated Black women (FIBW), a qualitative narrative analysis research study was conducted. Data were drawn from participants' written responses to writing prompts given over a six-week period. Participants included 7 FIBW between the ages of 44-63 who all shared a history of substance abuse and were either engaged in a postsecondary educational program or completed one. The Strong Black Woman schema emerged as an overarching life perspective that impacted the participants' behavior, coping strategies and development of characteristics. Three characteristics emerged from the data: Strong Advocacy Skills, Socially Resourceful/Excellent Hustler, and Spiritually Connected. The implications from this study suggest: 1) There is a need for culturally affirming training for educators at all levels of education (K-20) to better inform them of approaches for working with Black females. 2) Certain street behavior was useful for reaching academic goals; 3) Gender responsivity does not address the intersectionality involved with being a Black woman. An approach for building on Black women's unique strengths, needs and characteristics, the Araminta Approach, was also introduced. This narrative inquiry research demonstrates the tremendous potential that exists among FIBW, and it provides a pathway for the criminal justice system and academia to unleash it.

I certify that the Abstract is a correct representation of the content of this dissertation.
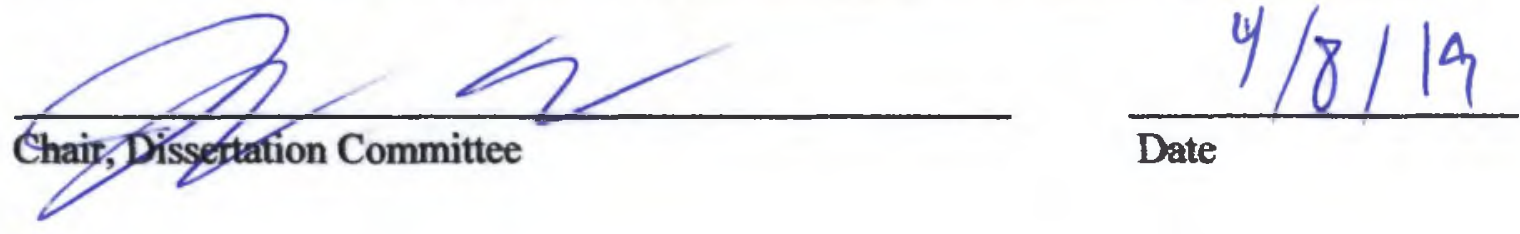


\section{ACKNOWLEDGEMENTS}

I would like to thank God for loving and nurturing me when I was unable to love and nurture myself. Second chance is a jargon that is thrown around, but I want to acknowledge that I have been given umpteen chances. Thank you Lord. I would like to give a shout out to Dr. Jamal Cooks for not quitting me during this process, Dr. Robyn Fisher for being a ride or die, and Dr. Stanley Pogrow for being patient with me and for keeping his hands off of my computer (inside joke). This dissertation was written in remembrance of every member of my tribe that was lost in the crack epidemic. I love and miss you all dearly. Fillmoe for life! I would like to thank my deceased grandparents, Mai Mai and Pa Pa (pronounced May May and Paw Paw), for taking on the responsibility of raising me for the first 9 years of my life, loving me unconditionally throughout my adulthood while they lived, and introducing me to the importance of education. Carlotta Marie Francois, your daughter is a doctor now! Rest in peace knowing that! Black sheep are often misunderstood, so I misunderstood who you were and what you meant to me. I'm dedicating this entire dissertation to you Carlotta. I love you, and I miss you so much! I had to show up and out just for you. You were my mom, and I never called you mom while

you were on this earth because I didn't know how to. It was complicated. Today, I am saying RIP MOMMY. To the six people I gave birth to, I wish I could undo what I've done, but I can't. Nevertheless, I hope this changes our family's, your babies' and future babies' legacy. This is my version of saying sorry. Please forgive me. 


\section{TABLE OF CONTENTS}

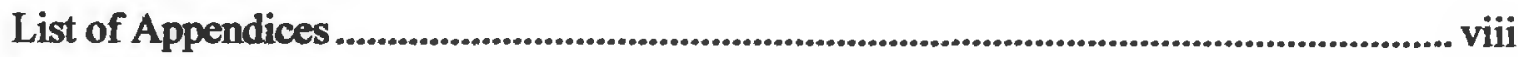

Preface

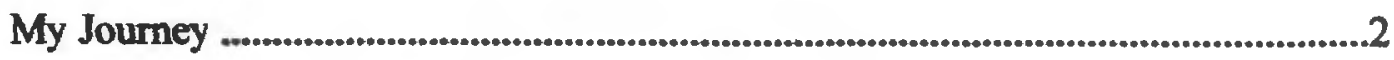

Chapter One: Background Information and Purpose of the Research...................................7

Statement of the Problem ...............................................................................................................7

Study Significance ...............................................................................................................9

Chapter Two: Literature Review ......................................................................................13

Theoretical Framework: Intersectionality and Black Feminist Thought .................13

The School to Prison Pipeline and Black Females ..............................................15

The Strong Black Woman Schema .............................................................................18

Gender Responsivity vs. the Strong Black Woman Schema .....................................24

Spirituality..................................................................................................................................29

Conclusion ...............................................................................................................32

Chapter Three: Methodology ................................................................................................................35

Methodological Approach: Narrative Inquiry ..........................................................35

Participants' Beckground..............................................................................................37

Data Collection ..................................................................................................................48

Data Analysis ..........................................................................................................................50

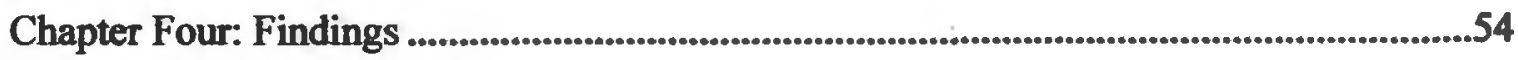

Strong Advocacy Skills..................................................................................................54

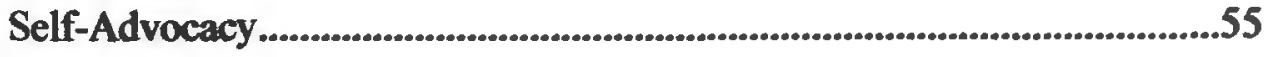


Community Advocacy .....................................................................................662

Socially Resourceful/Excellent Hustler ...................................................................64

The Hutle ........................................................................................................64

Ability to Build Social Capital............................................................................67

Spiritually Connected....................................................................................................70

Existential Purpose..................................................................................................71

But God.............................................................................................................................73

Chapter Five: Discussion and Implications ................................................................77

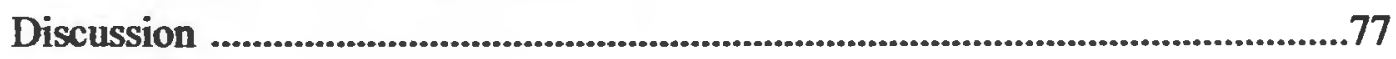

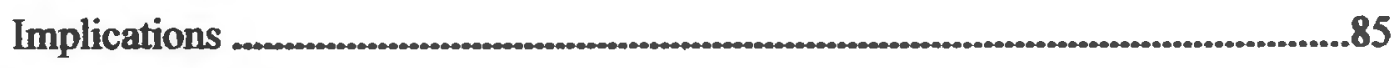

Limitations ..............................................................................................................................97

Conclusion

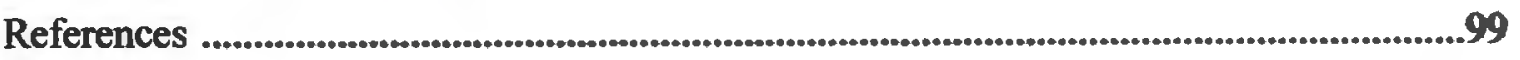

Appendices .................................................................................................................................107 


\section{LIST OF APPENDICES}

Appendix

Page

1. Demographic Survey .......................................................................................100

2. Writing Prompts........................................................................................... 102 


\section{Preface}

I searched my heart to find the message I would like to leave you with today. Who knows the next time I will be able to speak to such a large crowd? Some of us have a rougher time attending college than others. For some, the road to college is a wide road; for others, it is like walking on a tightrope. For some the war in Iraq is the issue of top priority, but for some of us it is the war right outside our doors. Just the other day my community buried a 17-year-old Black boy who was killed in the streets of San Francisco. Ironically, while we were attending the funeral, another young Black man was killed a few blocks away. I had a final that night, and I couldn't bring myself to concentrate, so I left early. This scenario is just a glimpse of what people living in the ghetto have to endure while pursuing an education. This has been a rough battle, but I had something to prove to society and myself, so I kept climbing. I had to set an example. Media, where are you? I know you are up in here because the mayor is up in here. I need you to do me a favor because my community is experiencing a lot of disappointments, and we need some good news, so I was sent here to represent. I need you to tell the people that a Black woman, an ex-convict, an ex-addict, living in the projects, graduated with the highest honors this morning...(Jones, 2013, p. 112).

This is an excerpt from my Salutatorian speech during my community college graduation. The scene was a mixture of standing ovations, people screaming and hollering, and young Black men from the Black Student Union literally barking. My fiveyear-old son clapped for me and shouted "Mommy!" the entire speech. My entire family was there: my grandmother, my husband, my aunt, my cousins, my children, my mom and my sister on my mom's side. As I ended with the above statement, I saw people jumping out of their seats in approval of my words. That night we (my family, friends and neighbors) partied until 4 a.m. Every few hours, I would raise my hands in the air and everyone would cheer, "Yay, Marilyn!" I took full advantage of that, and I had them to do that one final time before I announced I was going to sleep and the party was over 
around 4 a.m. the morning following the graduation. To this day, people from my community remind me that I am educated and praise me for it. (Jones, 2013 p. 111-114). For the first time in my life, I was the cause of joy and happiness for my family by graduating with an Associate degree.

The above-mentioned day remains by far the best day of my life. It wasn't easy, but I worked relentlessly to obtain good grades while raising four children. It was a long road to get there. I was able to make amends with my family, particularly my grandmother, the woman that raised me and never left my side even when I was at my worst. Making my family proud wasn't always the case. My story of how I reached that special day of redemption is described in my personal autobiography, From Crack to College and Versa (Jones, 2013). I have drawn from this work throughout this dissertation. My reason for choosing to include my autobiography is that I wrote it during a very vulnerable and painful period of my life, which enabled me to speak from my inner, truthful voice.

\section{My Journey}

I was born in October of 1964 during the Civil Rights Movement. My mother was 15 years old when she gave birth to me. Due to my mother's tender age, her vulnerability to predatory grown men, and her mental instability as a result, I lived with my grandparents for the first nine years of my life in the Western Addition in San Francisco, CA, a former predominantly Black community. The Western Addition also 
known as The Fillmore is colloquially known as Fillmoe, a term I embrace. Fillmoe used to be a vibrant Black community filled with Black owned businesses and property.

Although my grandparents were not highly educated (my grandmother was a high school graduate, and my grandfather was a high school graduate who had earned a barber's license) they both were very avidly concerned and involved with my elementary school education. I was an extreme nerd that read encyclopedias for information on a daily basis when I lived with my grandparents. At the age of six, my grandmother bought me a blackboard for my room, and I used to teach her double digit math and how to print because she only knew how to write in cursive. She would sit in my room as my student. I think back to her level of humility and patience with me, and I realize how much she helped to mold me as an educator. As an adult, I also realize that my grandmother may have been able to do some of the things that I was teaching her to do. Nevertheless, she played the role as my needy student ever so well.

While in my grandparent's care, I was deemed to be a gifted child by the elementary school I attended. As a result, a few of my teachers took me home to spend the night with them and gave me preferential treatment. I remember my $3^{\text {nd }}$ grade teacher, and Asian woman, explaining to me that what she was doing with me wasn't allowed, so I had to act like it wasn't happening. I played along with it and did not say anything, but it was somewhat confusing for me at such a young age. During class, my $3^{\text {rd }}$ grade teacher would act like I was not special, but after school she would show me a great deal of love and attention. I remember spending the night at her house in the city of 
Marin. When I was in the $2^{\text {nd }}$ grade, I also remember spending the night a few times with another teacher from my after-school program in the Haight Ashbury; she taught me how to crochet and cooked really good potato soup for me.

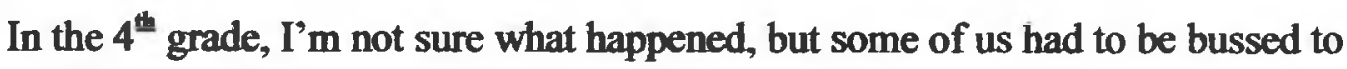
another school that was more integrated. I no longer received preferential treatment. There would be no more singing the Black national anthem, African dancing or Swahili classes. I also lost the gifted status that I had at the all-Black school. I cannot remember one teacher in the school I got bussed to. I can remember all of them at John Muir Elementary School, the school that taught me it was a beautiful thing to be Black. At the same time, my father began to show interest in me, and I eventually moved in with him, his girlfriend, and their children. The household I moved into didn't value education as my grandparents did. They put more emphasis on their children's toughness, and that household was abusive on many levels. I was beaten, fondled, and verbally humiliated on a regular basis. My spirit became weary. I had to harden myself to cope.

I experienced my first and unearned endeavor with juvenile hall as a result of being in this household (my father's girlfriend called the police on me for basically nothing). My first bout of incarceration lasted one month and 20 days, but the impact would go on to last a lifetime. Juvenile hall literally taught me how to accept being imprisoned. I was incorrigible when I returned to society and beyond my grandparent's ability to save. From the ages of 14-19, I lived my life at the mercy of the streets that had no mercy despite the fact my life was preserved. In the mid 1980's I gave birth to my first 
child at the age of 19 and became pregnant with my second child three months after his birth. During the same time, my community was bombarded with a new, highly addictive drug, crack cocaine. The next excerpt is what came to follow:

At the age of 20 I had been on crack cocaine for approximately six months when an elderly woman asked me with a disgusted look on her face, "Have you looked in the mirror lately?" Later on that day, I took a good look in the mirror, and I must admit that it saddened me. I guess I hadn't looked in the mirror for at least six months, which is how long I had been on dope. As I examined myself, I first noticed that the white schoolboy shirt I had on was damn near brown, and I then realized that I hadn't changed clothes in weeks. I began to examine myself more closely and focused on the person in the mirror wearing the grimy clothes. I saw a shell that used to be my body; there were bones visible in my chest and face that I had never seen before.

My hair was dry, brittle and lifeless looking, and my skin had a grey-blue tint, but the worst part was my eyes. I saw eyes that no longer had a spark of hope; they looked like empty deep pools, but ironically my eyes were the only part of my body that resembled the old me. Somehow they were still pretty. It was really sad because my eyes seemed as if they had been kidnapped and wanted to be rescued; they began to tear up. I had to look away, so I was unable to connect with that person in the mirror. Although I was unhappy with what I saw, I was too far gone in my addiction with a lot more mileage left on my feet to make any changes. The crack wouldn't allow me to [make any positive changes in my life] at that point. I now had another reason to smoke dope: to help me avoid myself (Jones, 2013, p.6).

The above-mentioned day, the day I resigned to the fact I was a severely addicted drug addict, was one of the most humiliating and hopeless days of my life with many more days like this to follow. My sense of powerlessness was beyond my ability to fully comprehend at that tender age; nonetheless, I submitted. I had no control over myself anymore. I spent the next 15 years in this state of mind, recidivating back and forth to 
jails, prisons and self-help/drug programs. The transformation from being a drug addict and former prisoner to a scholar didn't happen overnight.

The process of transforming from an addict to a scholar was an incremental and somewhat surreal process as I look back. This incremental process that led me through the identity of an innocent child to a prisoner, which began with a dysfunctional family and traumatic childhood, being pushed out of public school into the streets and into juvenile hall, my community being bombarded with boatloads of poison/crack cocaine, and me taking the bait. Somehow I made it back from this horrible ordeal and was able to become educated. I have the privilege of having a few of my peers and colleagues that have undergone the transformational process from prisoner to scholar, who also happen to be Black women, whom I have chosen to affectionately name The Comeback Queens.

Although my odds of succeeding in life were minimal at various stages of my life, I managed to survive, figured out how to somewhat thrive, and found my way to academia. I have had the opportunity to live two lives. My best and worst day represent an oxymoron. The day I the day I realized I was addicted to crack cocaine was the worst day of my life, and the day I graduated with an Associate Degree in Liberal Studies was the best day of my life. The extreme differences between these two days is representative of the two lives I have been allowed to live. Although the differences are extreme, I have discovered I am not alone. I have been privileged to know a few Black women that have undergone the same circumstances. 


\section{Chapter One: Background Information and Purpose of the Research}

\section{Statement of the Problem}

I have over 20 years' life experience living in public housing as an adult. There is nothing I have read in an academic space that has come close to what I have experienced. I moved into a public housing site, Hayes Valley North, Page Street projects in 1985. A few months after I moved in to the Page Street projects, public housing sites in San Francisco, including the one I was living in, predominantly occupied by Black residents with female-led households, became infested with crack cocaine, and the community devastatingly fell apart. The following is an excerpt of a newspaper article published in the New York Times written by Reverend Cecil Williams, the founder of Glide Memorial Church:

Black crack dealers have told me that their primary targets are black women. If you get to them, you get to children and you get to them, you get to the children and you get to men. Addicted women and mothers, crack babies doomed to a severely limited existence, a large percentage of a race exposed to courts, probation and jail time: if nothing is done soon, this will be the future of the black community (1990).

Reverend Williams was well aware of the matriarchal hierarchy in the Black community as were the crack dealers he communicated with.

Academia constantly emphasizes the patriarchal make-up of society. However, I lived in public housing in San Francisco for over 20 years of my adult life, and my experience is quite the contrary. After the epidemic subsided to some degree, I was able 
to see the importance of Black women in public housing sites. Black women controlled the speed limits of cars driving through the public housing site I lived in that were driven by drivers who were acting upon fear and not considering the young lives that could be lost due to their speeding. Black women were the mediators for fights that were about to happen among the youngsters from different sets (housing complexes) in the community. Black women hosted functions that brought the community together and, Black women were who the youngsters confided in for help navigating through the vices of living in public housing (eg. drugs, violence, deaths, etc). This was not the case during the crack epidemic.

\section{Mass Incarceration and Black Women}

In response to the crack epidemic, the United States government created harsher criminal justice policies that resulted in Black women from drug-infested communities becoming incarcerated at record levels (Bush-Baskette, 1998). The incarceration of Black females at record highs severely impacted the overall morale of the community. The community could not handle the loss of its backbone, Black women. During the crack epidemic, the community lost a great deal of support, advocacy and overall rationale capabilities that was previously assigned to Black women as gatekeepers, and the value of life in the Black community depreciated. Due to the backbone of the Black community, Black women, being systematically removed from the familial equation in numbers, the community suffered drastically. 
Although the nation as a whole has improved in regards to incarceration disparities, there are still some cities that suffer from extreme disparities. San Francisco, $\mathrm{CA}$, is one of the cities that was severely impacted by the crack epidemic in the mid1980 s and on through the 1990 s, and the extreme incarceration disparity for Black San Franciscans continues to this very day (Burns Institute, 2015; Males, 2015). Over 30 years later and despite gentrification efforts that have dwindled the Black population in San Francisco, CA, the incarceration disparity among Black San Franciscans is still at a crisis level. In San Francisco, Black women account for $5.8 \%$ of the general female population; however, we represent close to $45.5 \%$ of the women arrested (Males, 2015) and over $44 \%$ of the incarcerated female population housed in the San Francisco County Jails (Burns Institute, 2015). The matriarchal hierarchy of the Black community in lowincome settings points to our extreme importance (Davis, 2015; Donovan, 2015). Black women's positionality and centralized stronghold on our communities also points to us for answers. Without the support of Black women, the Black community withers.

\section{Study Significance}

The purpose of this research study is two-fold. The first purpose is to gain a better understanding of the mindset and actions of FIBW that have managed to make the transition from the criminal justice world to academia. The second purpose is to gain a better knowledge of myself. Gaining a better insight into my mindset is something that will help me to become a better prepared leader and researcher because I can begin to identify my biases, strengths and areas that have room for growth. 
The plight of Black women in the criminal justice system has been overlooked. I have searched for over $1 \frac{1}{2}$ years and have yet to find an empirical research study that is designed to highlight the unique educational strengths, needs, or experiences of incarcerated or FIBW. This dissertation serves as an introduction to a worthy population. Black women are greatly impacted by the criminal justice system. Not only are Black women incarcerated at disparate rates, but Black women also have to foot the bill for our incarcerated loved ones in the form of accepting collect calls, spending money traveling to different locations to visit absent loved ones, and providing for our families in their absence (Essie Justice Group, 2018). One in four women in the United States have an incarcerated loved one. This number doubles for Black women. It has been reported that one out of two Black woman has an incarcerated loved one, and this has a significant impact on Black women's mental health and financial stability (Essie Justice Group, 2018).

Moving forward, the unique needs and traits of FIBW must be explored in order to adjust educational and criminal justice policies and practices, or a severe injustice will continue. Solving the disparity of the effects of incarceration on Black women requires adjusting educational and criminal justice policies, which can be accomplished developing a better understanding of the unique needs and traits of FIBW Incarceration is costly on a monetary level for society overall, but the Black community pays the ultimate price because it doesn't function very well in our absence. The answer for many of us may lie in academic engagement. 
Research has found that the more educated a person in the general population is, the less likely they are to become incarcerated (Harlow, 2003), and incarcerated populations tend to be less educated than the general population, but if their level of education while incarcerated they are less likely to return (Vacca, 2004). Nevertheless, incarcerated and formerly incarcerated Black women's needs and experiences are still virtually invisible in educational and criminal justice research literature. This lack of attention is unethical because the association between incarceration and education is too strong for researchers and policy makers to continue to overlook us.

In the penitentiary, there is a practice that takes place to make sure that none of us have escaped, it is referred to as "count time". When everyone has been accounted for, it is announced over the loud speaker that the "count has cleared." Researchers have taken on the roles of correction officers by merely identifying the Black and white incarceration disparity in a quantitative method, i.e., as a count. The count by both researchers with doctorates and jailers has cleared many times without viewing it from an empathetic lens. The completion of this dissertation symbolizes the moment the practice of merely counting us comes to an end.

The completion of this dissertation has also been helpful with my professional development. I am the Founder and Executive Director of Because Black is Still Beautiful (BBISB), a nonprofit organization with a mission statement that reads as follows: "Dismantling historic perceptions, practices and policies that negatively affect criminal justice impacted Black women while building upon our strengths Because Black 
is Still Beautiful." One program under the umbrella of BBISB is entitled Just Say Know (JSK). JSK is a culturally affirming program that is designed to promote academic engagement among criminal justice impacted Black women or those at risk. Thus, answering the research question increases my ability to serve the population I target.

\section{Research Question}

The research question for this study is as follows: What are the social/emotional and academic characteristics of FIBW that made the transformation from a prisoner to a scholar?

Black women's demise lead to the fall of the Black community in America. I am identifying the fall of the Black community as the crack epidemic and the aftermath, including the separation of a multitude of Black families (Fullilove, Lown \& Fullilove, 1992), and subsequently the rise in Black-on-Black murders among the Black youth in America (Davey \& Smith, 2015), the lack of Black ownership in neighborhoods we once reigned, and the lack of attention and protection given to Black women as the matriarchal queens of our neighborhoods. We are valuable and worthy, and it is time that the criminal justice and educational fields acknowledge us as such. We are worthy of being researched in a manner that not only quantifies our pain but reflects our strengths. 


\section{Chapter Two: Literature Review}

The following strands will be covered in this literature review: the Theoretical Framework, the School to Prison pipeline and Black females, the Strong Black Woman Schema, Gender Responsivity Versus the Strong Black Women Schema, Yosso's Community Cultural Wealth Model, and Spirituality.

\section{Theoretical Framework: Intersectionality and Black Feminist Thought}

Several layers of identities (race, gender, class, criminal history) intersect and must be considered when seeking to understand the experiences of FIBW. Gender responsiveness, a theoretical approach coined by Bloom, Owen and Covington (2003), is an approach that is widely accepted by criminologists to promote favorable outcomes among incarcerated and formerly incarcerated women due to the increased number of women in the United States who exist in a system that was designed for men. However, gender responsiveness can be interpreted as a color-blind approach.

In order to develop effective strategies that create optimal results in the lives of FIBW, gender and race should be considered. According to Crenshaw (1991), antiracist practices were designed for Black men and concludes that a theoretical stance coming from a purely feminist or purely anti-racist point of view marginalizes the experiences of Black women. This intersectionality may expose FIBW to multiple levels of domination and oppressive practices (Crenshaw, 1991). Therefore, relying only on gender or racial approaches by themselves can lead to Black women's needs not being met nor addressed. 
FIBW are members of various formerly incarcerated groups. For example, FIBW can be considered formerly incarcerated people, formerly incarcerated Black people, as well as formerly incarcerated women. Unfortunately, being able to blend into the various categories has led to FIBW's uniqueness, strengths, capabilities and characteristics being drowned out in the empirical literature. Black feminist thought (BFT) is a theoretical framework that acknowledges the subservient history and current status of Black women, the complexities involved with intersectionality, and it is designed to battle these oppressive factors from the standpoint of Black women (Joseph, N., Viesca \& Bianco, 2016). Collins (2002) developed BFT to find her voice that she determined had been lost due to her exposure to corporate white America.

BFT appealed to me because it represented an empowering sense of Black female identity as unique and powerfully whole unto itself. BFT was not created to challenge or compare it to more enunciated feminist theories developed by white women. BFT has been chosen as the foundational component of this dissertation because it highlights my personal experience as a Black woman and acknowledges those experiences as full and complete. The purpose of developing BFT was for the empowerment of Black women. Collins recognized that "...empowerment of African American women will never occur in a context characterized by oppression and social injustice" (p.x). Collins set out to develop a theory that not only appeals to academia but can also be understood by the masses, particularly Black women. She further explains, “Approaching theory in this way challenges both ideas of educated elites and the role of theory in sustaining 
hierarchies of privilege" (p.vii). I also found it interesting how Collins (2002) felt it was freeing to insert herself in the text by using the words " 1 ", "we" and "our" in opposition to "...more distancing terms such as they..." (p.ix). BFT speaks to my need to be encouraged and encouraging.

It was important for me to incorporate a theoretical framework that would serve as tunnel vision in order to pay close attention to the intersectionality and uniqueness that exists in the lives of Black women and to best represent FIBW despite two very oppressive systems that often work in opposition of upward mobility, K-20 education and the criminal justice system.

\section{The School to Prison Pipeline and Black Females}

The road to involvement within the criminal justice system often begins during $\mathrm{K}$ 12 education (Mallet, 2016). In order to gain a better insight of FIBW, it was important to revisit the only point of our lives that we are present in the literature as students, during $\mathrm{K}-12$ education. The process of becoming institutionalized and indoctrinated into the culture of incarceration was an incremental process that began at the age of 13 after I was expelled from middle school. Consider the following:

When I first got to Hillcrest [juvenile hall], I was extremely mad and would throw temper tantrums. I can't remember why, but I do remember having my socks and shoes pulled off and being literally dragged to the hole, solitary confinement. I stayed there or a week or two. I could have gotten out sooner, but every time the juvenile staff came to talk to me, I cussed them out. I was angry, and they didn't try to figure out why; again, I was made to believe I was just a bad child. After a 
while, I gave in. The time in the hole broke me. I was eventually allowed to go back into the general population; I was broken to the point that I started helping pass out toothpaste and soap in the mornings, so I could be out of my cell... At first I was very bitter, but I learned how to "program," a term used by correctional staff that means you have the ability to adjust to the loss of freedom well. Now that I think about it, I don't believe learning how to cooperate with the policies and procedures that are imposed in a locked facility is a positive quality that children should acquire (Jones, 2013, p.18).

Although Black women are the focus of this paper my experience suggests, it is critical to consider the starting base of the school to prison pipeline that begins during $\mathrm{K}$ 12 education. Mallet (2016) defines the school-to-prison pipelines as "a confluence of two child- and adolescent-caring systems-schools and juvenile courts- that simultaneously shifted over the past generation from rehabilitative to punitive paradigms" (p 1). The punitive nature is the essence of the school-to-prison pipeline. The school-toprison pipeline is not designed to understand the complexities involved with maturing through childhood and adolescence; instead, it is designed to punish children, particularly children of color.

Although the educational experiences of FIBW are not adequately represented in the literature, recently researchers have attempted to capture the educational, punitive experiences of Black girls (Annamma, Anyon, Joseph, Farrar, Greer, Downing

\& Simmons, 2019.; Blake, Butler, Lewis \& Darensbourg, 2011; Morris, 2016; Wun, 2016). Black girls are most likely to receive disciplinary actions at school due to defiance (Annamma, et.al, 2019; Morris, 2016, Wun, 2016), which is subjective to interpretations more often than not by white teachers (Blake, Butler, Lewis \& Daresbourg, 2011). Blake 
et.al. (2011) speculated that the behaviors Black girls were excluded from school for defied traditional standards of femininity and paralleled with negative stereotypes. Interestingly, the faculty for this study was $78 \%$ female and $90 \%$ white. This points to the fact that white female teachers are likely to impact Black female students adversely.

Even worse, there is evidence that some Black girls who are disciplined at school are also undergoing traumatic childhood experiences. Wun (2016) conducted a qualitative study on school punishment with 15 Black girls found that five of the 15 Black girls received disciplinary actions while they were undergoing traumatic experiences (e.g. lack of food at home, abuse, overly responsible for their siblings' care, sex trafficking, etc.). Wun's interviews with these five girls revealed that they were misunderstood and received disciplinary actions in their greatest times of need. Wun compared this treatment to that of a slave woman who is not allowed to feel but must keep working. Wun referred to this concept as "the afterlife of slavery". Unfortunately, the Black girls in Wun's study had a keen awareness of the discriminatory practices and surveillance measures that they faced once they were deemed to be a problem by the school system.

This high level of awareness regarding the cultural inequities related to obtaining a formal education does not go away once Black girls have grown up and experienced being in prison, and in some cases these negative memories of school are vivid in my experience and Wun's study. Resentments towards the school system begins to form and continue to grow. In turn, the policing behavior of the schools intensifies. This 
incremental process results in Black girls being out of schools and into prisons (Morris, 2016).

Due to being undereducated when they went to prison, Black women return to their communities facing greater obstacles reintegrating and having higher rates of recidivism than all other women (Burns Institute, 2015). The overly punitive process in both schools and prisons leads to a lack of trust and hopelessness in the lives of FIBW, which leads to the cycle of ongoing recidivism.

\section{The Strong Black Woman Schema}

Due to the extreme correlation between human beings' mindsets and the behaviors we engage in, it is of utmost importance to gain a better understanding of the mindset of many Black women. According to the literature, the Strong Black Woman (SBW) schema is a coping mechanism adopted by Black women who were held as hostages, raped at will, and forced to work tirelessly for hundreds of years without compensation that was passed down inter-generationally (Donovan \& West, 2015). This hypothesis is hard to fully accept without knowing what roles African women played in their African communities prior to becoming enslaved. What I do know is that African women who arrived to America alive following one of the most horrific boat rides recorded had to be strong.

The SBW schema has been addressed under several different terminologies, (Watson \& Hunter, 2016), such as but not limited to "Superwoman, Modern Mammy, 
Black Lady and Sojourner Syndrome" (Donovan \& West, 2015). The commonality that exists among all of these titles is that there are self-regulated, adopted sets of cognitive and behavioral expectations that exists within the minds of many Black women in America for survival in response to oppressive practices (Abrams, Maxwell \& Belgrave, 2014; Beauboeuf \& Lafontant, 2007; Donovan \& West, 2015; Davis, 2015; Watson \& Hunter, 2016). The expectations involved with trying to live up to the above-mentioned titles are admirable but at the same time can be exhaustive and unrealistic.

The following themes are highlighted across the literature in regards to the tenets involved with the SBW schema: a SBW strives to be an excellent caregiver (Abrams, et al., 2014; Beauboeuf \& Lafontant, 2007; Donovan \& West, 2015; Davis, 2015; Watson \& Hunters, 2016); a SBW has a strong sense of ethnic pride and strives for the mastery of self-reliance (Abrams et al., 2014; Donovan \& West, 2015; Davis, 2015); a SBW is not afraid to advocate for herself (Watson \& Hunters, 2016), and a SBW operates under a belief system that she has the ability to perform favorably despite the acts of oppression that consistently work in opposition to her state of mind (Donovan \& West, 2015). These sets of expectations are omnipresent in Black communities (Abrams et al., 2014). The SBW identity is highly revered and celebrated in the Black community (Davis, 2015), and she serves as the almighty confidant (Donovan, 2015). The high level of confidence within the matriarchal hierarchy in the Black community is robust (Davis, 2015; Donovan, 2015). In laymen's terms, the Strong Black Woman takes on the role of the ultimate caregiver and backbone in the Black community. 
One attribute of the SBW schema, the desire to be the ultimate caregiver, was brought to the surface in the findings of Heidermann et al. (2016b). Heidermann et al. conducted a cross sectional, mixed methods study that was designed to explore triangulation among the factors of helper/wounded healer orientation, self-esteem, and social support among formerly incarcerated women. The helper/wounded healer orientation is a theoretical framework that conceptualizes the culture of "giving back," which formerly incarcerated people tend to do with their peers who are not as far along in the recover/reentry process (Heidermann et al, 2016b). The quantitative data from this study consisted of 104 structured surveys, and the qualitative date consisted of 30 indepth interviews conducted with a sample population that was predominantly Black women. The quantitative findings revealed that $78 \%$ of the sample agreed or strongly agreed that assisting others helped them avoid making mistakes, and $61 \%$ of the participants of this study wanted to pursue a career in helping others. The qualitative findings of this predominantly Black female sample revealed a culture of giving back and a moral code that exists among reentry populations, and having this ability to reach back was found to be a strong source of self-esteem building (Heidermann et al. 2016a).

This theme of wanting to nurture was also derived to by Leverentz (2011). Leverentz conducted a qualitative, longitudinal research study with 43 FIBW and repeated interviews with 30 of the participants every three to four months. Although most of the women in this study reported abuse from their families of origin, rarely did they want to sever ties, and having the ability to care for family members was extremely 
important to the participants, which is in direct alignment with the SBW schema. Heidermann et al. (2016) highlighted how "giving back" is beneficial to women and helps them to stay on track, but Leverentz (2011) suggested that this ideology is actually a need for FIBW because it was not always based on positive outcomes in the past and may be against their own interests. Although these research studies are not designed to determine the unique needs or wants of FIBW, the skewed participation rate of FIBW in these studies allows their voices to be magninied. It should be noted that although Leverentz (2011) and Heiderman et al, (2016) conducted studies with participants that were predominantly Black women, $65 \%$ and $100 \%$ respectively, neither one of these researchers sought to address their participants' uniqueness, meaning the Black part was only mentioned in the description of the participants.

Aithough the Strong Black Woman serves as a beacon of hope for her community, there are complexities involved that are associated with the promotion of both positive and negative outcomes in many Black women's lives (Abrams, et al., 2014; Belgrave, 2014; Beauboeuf \& Lafontant, 2007; Donovan \& West, 2015; Davis, 2015; Watson \& Hunter, 2016). While the research reviewed addressed both positive and negative outcomes associated with the SBW schema, the main focus was on the negative impact associated with how the SBW schema manifests in the form of poor mental health outcomes for Black women (Donovan \& West, 2015), which can lead to poor physical health. 
The oppositional, omnipresent factors that constantly work against the state of mind associated with the SBW schema, such as but not limited to racism and sexism (Lewis, Mendenhall, Harwood, \& Huntt, M. B., 2013), can lead to tensions and turmoil within (Watson \& Hunter, 2016). Donovan \& West (2015) found that Black women with moderate or high levels of the SBW schema endorsement were far more prone to be dealing with high levels of stress and depressive symptoms. High levels of stress may be attributed to the inability to express pain or ask for help in overwhelming situations due to the almighty role SBW attempt to play (Abrams, et al., 2014; Beauboeuf \& Lafontant, 2007) as well as the selfless nature of this schema. It should be noted that the silence is not totally due to the inability to express pain, but it is also due to the role family and the greater community expects SBW to fulfill (Davis, 2015; Donovan, 2015). One may attribute the SBW schema to poor mental and physical health outcomes (Donovan \& West, 2015), but it must be also understood that the SBW schema is a coping mechanism. It is an adapted response to sexism and racism which are also root causes of poor mental 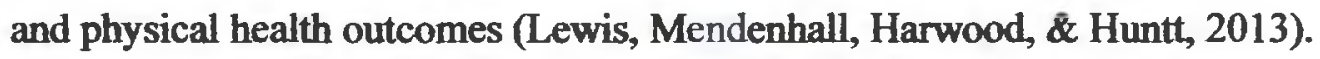

Strong self-advocacy skills among Black women should be recognized as a strength and agency, but this skillset is often mistaken to fall under "the angry Black woman" stereotype (Lewis, Mendenhall, Harwood, \& Huntt, 2013). Lewis, et.al. (2013) conducted a research study that was designed to examine the coping strategies in response to racial macroaggressions among 17 Black women ages 19-39 years old that were engaged in undergraduate, graduate, and professional studies. 
Lewis, et.al (2013) found five themes were identified for coping strategies that Black female students engaged in:

...two resistance coping strategies (i.e., Using One's Voice as Power, Resisting Eurocentric Standards of Beauty), one collective coping strategy (i.e., Leaning on One's Support Network), and two self-protective coping strategies (i.e., Becoming a Black Superwoman, Becoming Desensitized and Escaping). In addition, we uncovered a secondary appraisal process of Picking and Choosing One's Battles, which describes the process of making decisions about when and how to address gendered racial micro-aggressions (p. 59-60).

Although the Black women in this study were not identified as formerly incarcerated, their way of coping with the oppressive nature of postsecondary education by way of the SBW schema is notable. The title of being formerly incarcerated is not an explanation of our identity in totality. It is just a portion of who we are. The coping strategies that Black female students have incorporated to survive in postsecondary educational endeavors are not exclusive to those who have not been incarcerated.

As mentioned previously the SBW schema is omnipresent among Black women, which includes Black women with a history of incarceration. We are still Black women. We have a history of trauma, but we are no different than our ancestors who handed this way of thinking down to us, so we can survive. When seeking to explore the social/emotional and academic characteristics of FIBW who have managed to succeed as scholars, all of the intersections should be considered. Therefore, it is of utmost importance to consider our thinking patterns, which in many cases involves the SBW schema. 


\section{Gender Responsivity vs. the Strong Black Woman Schema}

The intersectional identities associated with the SBW schema may cause criminal justice involved Black women's unique needs to be overlooked through approaches that are tailored to work for all women of different ethnicities involved with the criminal justice system. For example, the criminal justice field emphasizes the need for a gender responsive approach as a way to address the rising increase of incarceration in the lives of women in America (Covington \& Bloom, 2007). This theoretical approach is widely accepted in the criminal justice system.

There are six principles associated with a gender responsive approach: 1) it highlights the acknowledgement that men and women behave and react differently to situations, which I find to be true to some degree, but it varies within racial groups; 2) an environment must be created to promote safety, dignity and respect; 3) polices, practices and programs that can be related to should be developed to promote healthy connections to family and significant others and the community; 4) substance abuse, trauma and mental health issues should be fully addressed in a culturally relevant manner; 5) women should be provided with opportunities to improve their socioeconomic situation; and 6) a system of community supervision and comprehensive services should be established (Covington \& Bloom, 2007).

As a mother of four Black males that have all been profiled by the educational and criminal justice system at some point of their lives and have required my support, I don't understand why the above-named principles are deemed to be gender responsive 
approaches. They qualify as humanistic approaches to say the least. The acceptance of these principles as gender neutral for women can serve as the justification for the mistreatment of America's hardest hit massively incarcerated population, Black males (Alexander, 2012).

Although there is a mention of cultural awareness and responsiveness as a component of the gender responsive approach (Bloom \& Covington, 2003), there are no recommendations on how to do so, which leaves the needs of the most impacted female population, Black women, to go unaddressed. The suggestion of cultural responsiveness without vivid instructions leaves it up to the imaginations of criminal justice staff that have previously operated under more punitive approaches. There is no mention of racism and its traumatic affects, and there is no mention of ways that people employed in the criminal justice field can address their own biases, which are apparent in the disparity statistics. The suggestion to utilize cultural awareness while using this approach is too vague, and this may strongly be attributed to the fact that the creators of this approach are white women who have not experienced being incarcerated.

A strengths-based style is also highlighted as necessary for the gender responsive approach (Covington \& Bloom, 2007), but it is contradictory based upon the foundational suggestion to acknowledge criminal justice involved women's plights through the engagement of a trauma-informed approach. To some degree, a trauma-informed approach implies a weakness and vulnerability as the foundation of this theoretical approach, and it may be in direct conflict with the Strong Black Woman schema. A Black 
woman that has adapted the SBW schema believes she is strong or at least is supposed to be strong, even while she is undergoing difficult situations in life (Abrams, et al. 2014; Beauboeuf \& Lafontant, 2007; Davis, 2015; Donovan \& West, 2015; Watson \& Hunters, 2016).

Gender responsivity is a theoretical approach developed by middle classed white women who have not taken the time out to understand the needs and thinking patterns of Black women impacted by the criminal justice system. I cannot place blame on them, but at the same time I cannot rely on their conclusions. It was significantly important to point out the gender responsivity approach because it has been widely adopted and accepted in the criminal justice field. The criminal justice system often doesn't consider the needs of Black people, and this is evident by the mass incarceration of Black people and the incarceration disparities that exist. Therefore, it was necessary to refute those who do not fully understand the scope of Black women's needs, strengths and ways to increase intrinsic motivation.

\section{The Community Cultural Wealth Model}

Although FIBW have a plethora of systemic barriers, it should be noted that this population has access to an abundance of cultural capital. Yosso coined the Community Cultural Wealth Model (CCWM) that somewhat encompasses the cultural capital or wealth that exists among people of color (2005). The CCWM is grounded in the Critical Race Theory, and it was created to contradict common beliefs about cultural capital and to put a hypothetical magnifying glass on the strengths that exist among non-white 
students. There are six components of cultural capital in the CCWM: Aspirational, Familial, Linguistic, Social, Navigational, Resistance (Yosso, 2005), but for the purposes of this study, Resistance, Navigational, Social and Aspirational Capital will be explored.

Resistance capital among students of color is founded upon historical, familial, and communal acts of resistance in a quest for equity and justice (Yosso, 2005). Formerly incarcerated women and men often engage in community activism and advocacy, forms of resistance to societal impacts on their communities, which assists them with reintegrating back into society (Veysey, Christian, \& Martinez, 2013). Their keen insight on issues that affect their loved ones and communities negatively can help to turn their wrongs to rights, and this can have a positive impact on their self-esteem (Veysey, Christian \& Martinez, 2013; Heidermann et.al., 2016b;). Thus, the combination of a college education with street and criminal justice experiences of formerly incarcerated Black people can assist them with becoming powerful change agents.

Navigational capital is also something that Yosso found to be present in college students of color (2005). Yosso describes Navigational capital as students' abilities to navigate through social institutions, including learning institutions. County jails and prisons are also social institutions. Many women and men, such as myself, develop lifelong ties in correctional institutions. Due to the extreme nature of the paths that the women of focus for this research study have navigated, this category is duly noted on behalf of them finding the path leading from adverse childhood experiences, to 
incarceration, on to academia. Academia is not noted as the ultimate institutions for change in this review, but it is a far cry from drug addiction and recidivism.

Social capital is a component of the cultural wealth model that emphasizes students' abilities to build their social networks, including their peers, and how well they are able to utilize this network to navigate through systems (Yosso, 2005). It is an important component because it may dictate how well someone is able to readjust and transition into society. For many formerly incarcerated people reentering society, a successful transition may require meeting a whole new set of peers. For formerly incarcerated students, this may require building social resources on campus as well as the community that are conducive to their quest to becoming educated.

Aspirational capital is another form of cultural capital that deserves attention. This area refers to the hopeful nature and ability to dream that many oppressed Black and Brown people have despite their situations (Yosso, 2005). Yosso doesn't give a reasoning behind people of color's ability to hope and dream despite ill conditions. Nevertheless, Aspirational capital is a huge factor that impacts students' abilities to achieve academically. In many cases, it was that glimmer of hope that enabled the thought of becoming educated in the first place.

The CCWM was designed to challenge what is known as wealth and who is wealthy, which is admirable. Some components of this model are very applicable to FIBW who are pursuing a higher education. Thus, the CCWM model can be to some 
degree effective in helping to answer the research question and determining characteristics of FIBW. However, to some degree CCWM is not entirely inclusive of the capital that exists among FIBW, which will be addressed in the Spirituality section.

\section{Spirituality}

During a pilot study that gave birth to this research study, the majority of the participants all paid homage to a higher power that had their best interest. The target population of this research study made drastic changes in their lives by choosing to enter postsecondary educational endeavors after exiting harsh life conditions, and the findings of this pilot study pointed to an abundance of faith. Faith and hope are tenets of spirituality. Spiritual capital is not addressed in the Community Cultural Wealth Model, but it is omnipresent in the Black community (Staton-Tindall, Duvall, Stevens-Watkins, \& Oser, 2013). Farmer-Hinton, Lewis, Patton \& Rivers (2013) conducted a research study in a Black community in St. Louis, MO, utilizing the Community Cultural Wealth Model as their theoretical framework, and they found that an asset in their community was missing, spiritual capital.

Spiritual capital and/or spirituality can take on different meanings, according to who is defining it. For example, Farmer-Hinton, et. al. (2103) were referring to religious ties in their community when they wrote about spiritual capital, which doesn't fully capture what spirituality is. Stanton-Tindall et. al. (2013) provided excellent definitions

of what spirituality entails, "[it is] a private, individual-level concept that is characterized 
by perceptions, beliefs, and feelings about a sacred or divine power, universal spirit or ultimate purpose", and it is a "sense of existential well-being which has been referred to as an understanding or belief in the meaningfulness of one's life" (p.2). Religion is associated with adhering to certain behaviors like attending church or identifying with belonging to a particular religious group (Stanton-Tindall, et.al, 2013). Both religion and spirituality have been found to be positive constructs for mental well-being (StantonTindall, et.al, 2013)

Stanton-Tindall, et.al. (2013) conducted a research study examining the extent to how the adherence to spiritual beliefs impacted the lives of 206 Black women with histories of substance abuse and traumatic life experiences. It was found that existential well-being is particularly important for Black women, and it was recommended that future studies incorporate spirituality into the assessment and treatment of drug addiction and mental health issues for this population. This thought of incorporating spirituality into the recovery from drug addiction is not a new concept. Narcotics Anonymous, a self-help drug treatment program that was founded in 1953, has 12 steps that are recommended for a person seeking relief from drug addiction to follow. Seven of the 12 steps refer to the reliance on God, a higher power or spirituality:

Step 1. We came to believe that a Power greater than ourselves could restore us to sanity.

Step 2. We made a decision to turn our will and our lives over to the care of God as we understood Him. 
Step 5. We admitted to God, to ourselves, and to another human being the exact nature of our wrongs.

Step 6. We were entirely ready to have God remove all these defects of character.

Step 7. We humbly asked Him to remove our shortcomings.

Step 11. We sought through prayer and meditation to improve our conscious contact with God as we understood Him, praying only for knowledge of His will for us and the power to carry that out.

Step 12. Having had a spiritual awakening as a result of these steps, we tried to carry this message to addicts, and to practice these principles in all our affairs (Narcotics Anonymous, 1984).

Spirituality has served many purposes in the Black community, and it has also been linked to resiliency in educational endeavors. One qualitative research study that was designed to determine self-perceptions of 28 Black single mothers in college found that were able to successfully engage in their roles as parents and students, and in some cases employees (Lashley, 2014). The complexity involved with fulfilling the different roles that Black single mothers who are also college students have to engage in was highlighted in this study. Lashley (2014) thought it was important to conduct her research in a manner that exposed the resiliency and strength of this often misunderstood population. The number of children that the participants of this study were raising ranged from one through four children (Lashley, 2014). Spirituality is one of the themes derived from this study; it was found to be a source of resiliency (Lashley, 2014). The following are excerpts provided by two participants of this study: 
"As a single parent, I would have to say that I provide guidance for my two kids by setting an example and just letting them know that some days can be hard and you can still make it throughout the day once you have that willpower and God.

"My major strength as a single parent is my inner strength, believing in God." These above-mentioned quotes from Black single mothers attending college speak to their faith in and reliance upon God to help them meet their duties as moms while attending college.

The quest for spirituality has historically served as a coping mechanism for Black people dealing with the harsh, inhumane and discriminatory conditions in the United States. An entire genre of music, Negro Spirituals, was created during slavery to call on a higher power to assist with the injustices enslaved people were facing (Perkins, 1922). The Black church was instrumental in the Civil Rights movement (Morris, 1996). During the Civil Rights movement, resistance, religion and spirituality worked hand in hand. Through these practices, the concept of spirituality has been passed down to descending generations in the Black community as a means of hope and intercession.

\section{Conclusion}

The research question was unable to be answered by this literature review. However, some of the information obtained in the strands were useful to move forward with conducting and analyzing the research. For example, the literature reviewed regarding the theoretical framework, which encompassed intersectionality and BFT, assisted with magnifying the gaps in the available empirical research. The lens of 
intersectionality and its recognized necessity for forming approaches that are effective for Black women (Crenshaw, 1991) enabled me to identify the vagueness and absence of Blackness in the highly recommended Gender Responsive approach. BFT helped to further hone in and center my focus on FIBW as the sole population of interest for this research study. Honing in aided with identifying the fact that although some studies I read in the criminal justice literature were comprised of sample populations that were skewed with a majority FIBW, the Black experience was absent.

The Black experience as well as the experience of addicted populations was present in the Spirituality strand, which helped to identify that the CCWM is incomplete because it doesn't capture the source of aspirational capital, spirituality, something that is of extreme importance in the Black community. The strand in this literature review that came the closest to identifying the academic characteristics among FIBW was the School to Prison Pipeline and Black Females; nevertheless, this strand fell short because the population of interest for this study are Black women, not Black girls.

The SBW schema strand was useful for me to become aware and evaluate a belief system and set of expectations for Black women that are omnipresent in the community. Through gaining understanding of this belief system, it better equipped my ability to visualize the total picture and gain insight into how certain characteristics may have developed for FIBW. Although conducting this literature review did not enable me to answer the research question, this process helped to identify huge gaps in the educational 
and criminal justice literature in regards to FIBW, shed light on the criminal justice system's lack of understanding of the mindset of Black women, and provided the knowledge needed to develop an adequate research tool.

In order to fill the gaps and lack of understanding, it is imperative that the lives of FIBW are analyzed with a lens that includes both race and gender. Race and gender are central to FIBW's positionality within systems of structural oppression. It has been determined by this literature review that an approach must be identified that holistically encompasses the needs of many Black women, which in many cases is the need to be strong. It would be inequitable to conclude this literature review by just identifying the gaps, instead I have chosen to identify the approach that is needed to gain a better understanding and provide suitable services to FIBW, which from this point on will be referred to as the Araminta Approach.

Araminta Ross was Harriet Tubman's birth name (Bedford, 1993). Harriet Tubman was a woman who suffered through a great deal of trauma and oppression, but she was very powerful at the same time. When attempting to understand the Araminta Approach one should ask themselves, "How would I approach Harriet?" The definition of the Araminta Approach is expanded more in Chapter 5: Discussion and Implications. 


\section{Chapter Three: Methodology}

In this chapter, the following areas are covered: Methodological Approach, Participants' Background, Data Collection and Data Analysis. The Methodological Approach section provides a detailed description of the methods utilized for this study and the references that influenced the decision to utilize this approach. The Data Collection section outlines how the data was collected and the rationale for doing so, and the Data Analysis lists the procedures followed to analyze the data.

\section{Methodological Approach: Narrative Inquiry}

Narrative inquiry was chosen to allow the voices of FIBW in a postsecondary setting, who have been invisible in the literature, to be heard. The criminal justice literature includes the bodies of Black women absent of the Black experience. The educational literature only discusses FIBW as problem children with no discussion of their lives as adults. Narrative inquiry allows their stories to be told for the first time. Due to the absence and lack of full attention, I believed that allowing the participants to be the authors of their own stories was the most ethical and equitable method.

I was also drawn to narrative inquiry because I wanted to gain a better understanding of myself. Utilizing narrative inquiry allowed me to tell my own story and relate it to others. As a Black woman getting a doctorate degree, one of my fears when I first started this program was that I would lose myself, particularly my Blackness. Instead of losing myself in the research, conducting narrative inquiry with Black women 
allowed me to validate and affirm myself, something that I rarely got the opportunity to do while pursuing this terminal degree.

The hunch I had that utilizing narrative inquiry as a method that could help me sustain my self-identity was validated by Brown et al.'s (1997) finding, which described the process of Black women researchers gaining a better insight of self through conducting narrative inquiry research. Brown et. al. (1997) put together an anthology of Black female oral narrative researchers' experiences and suggestions for conducting narrative research with Black women. They concluded that not only did conducting narrative research on Black women have a positive impact on the researchers' professional lives, but “their investigations have led to increased personal affirmations and feelings of validation about being Black and being a woman" (p.vii).

Narrative inquiry is a research tool that is designed to foster the elaboration of stories (Solorzano \& Yosso, 2002). Meier and Stremmel (2010) give an outstanding summation of narrative inquiry:

Narrative inquiry in qualitative research is a process of studying and understanding experience through storytelling or narrative writing...Stories are universal mirrors that show us the truth about ourselves - who we are and why we do what we do. ...Thus, narrative, as both a method and phenomenon of study, is a way of thinking about and making sense of experience (p.249).

This qualitative research study is designed as a collaborative narrative inquiry (Connelly \& Clandinin, 1990) with myself, the Principal Investigator, serving as a participant observer. Collaborative narrative inquiry is defined by Connelly and 
Clandinin (1990) as a "collaborative document; a mutually constructed story created out of the lives of both the researcher and participant" (p.12). Utilizing a collaborative narrative inquiry approach will allow me to better understand the social/emotional and academic characteristics of FIBW as a whole in order to promote positive outcomes in their lives, as well as meet my goal of gaining a better understanding of myself as a leader.

I determined that the best way to facilitate a fully constructed story would be to allow the participants to tell their stories in writing instead of verbally. This determination was made due to findings of a pilot study I conducted with a sample of FIBW with two forms of data collection: a 10-minute free writing session and a focus group. The writing responses proved to be far more powerful and heartfelt in comparison to the verbal responses. Possibly the process of writing allowed the participants to express themselves more completely without fear of judgment. The process of writing the responses also allowed the participants to spend some alone time while pondering upon the various experiences in their lives. Therefore, responding to the writing prompts allowed the participants to speak from their inner voice.

\section{Participants' Background}

The following is a collective description of the participants, including myself in the role of Participant Observer, based upon the Demographic/Eligibility Survey administered. All of the participants identified as Black or African American women. The 
study participants ages ranged from $44-63$ years old with a mean age of 54.6 years of age. All of the participants are residents of the San Francisco Bay Area with the exception of one participant who just recently moved out of state. The participants, including myself, approximated the total length of incarceration in our lifetimes, which ranged from 6 months to 10 years and was a grand total of 37.5 years. Although a history of substance abuse was not a criterion for participation, all of the participants of this study have overcome drug addiction with cocaine ( $\mathrm{n}=6$ crack cocaine and $\mathrm{n}=1$ powder cocaine) being the drug of choice. All of the participants were recruited through word of mouth. Due to my identity as FIBW I had access to this population from my personal and professional life.

\section{Participant Observer Profile}

\section{Marilyn}

I am a 54-year-old mother of six children, a native San Franciscan, and a resident of the San Francisco East Bay Area. I love to laugh loudly, dance, and I am a natural born fighter. My life took a turn that lead me down the path to incarceration when I started living in a home that didn't have enough to eat. My grandparents' home was full of food, but when I went to live with my father that wasn't the case even though his home was much more extravagant than my grandparents' home. I resorted to stealing to keep myself full. Stealing food was my introduction to living the lifestyle of a criminal. I was unbothered about the ethical implications because my stomach was full. 
My father's home didn't only lack food it lacked love. I suffered physical, emotional and sexual abuse in that household. As a result, I became a runaway, and I went on to engage in a lifestyle that consisted of me selling marijuana and stealing clothes for a living at the age of 14 . Unfortunately, this path led me to become vulnerable to the infiltration of my community with a highly addictive drug, crack cocaine. I lost all my morals and values, including my children chasing crack cocaine. Crack meant everything to me.

I have been to state prison five times, and I am not sure how many times I have been to the county jail. I realized that my life needed to change because I was very depressed and damn near suicidal for several years. There was not a single most important moment that made me change; it was a series of events. I no longer fit into this world, so something had to give, or I had to die. The thought of me dying a crackhead was overwhelming, and I somehow found the strength to walk away for the last and final time. What helped me stay away from trouble initially was writing my own autobiography, From Crack to College and Vice Versa. I literally cried for months while writing the book; it helped to begin a healing process.

By the grace of God, I will have 11 years crack-free this year. Due to all that I went through in my childhood, the crack epidemic, and prison, I suffer with bouts of depression and anxiety, and I have been diagnosed with Post Traumatic Stress Disorder. Nevertheless, I am a Doctoral Candidate that is anticipating graduating this year with a doctorate in Educational Leadership. I am pursuing a terminal degree as an act of 
resistance because I love doing the unexpected, and I have compassion for women like me that been demonized. I want to add us to the body of research as worthy and capable human beings, contrary to how we are often portrayed.

\section{Participants' Profiles}

The following is a profile description for each of the participants of this research study. Their names have been changed to protect their anonymity. The first paragraph is a broad description of who the participants are. The body of their profiles are writing samples taken from each participant, which describe their journeys into and out of lifestyles of addiction and recidivism verbatim. It was important for me to allow the participants to tell their own histories. Their recollection of their tumultuous backgrounds are engulfed in trauma, guilt, shame, pain and other feelings. I do not have the right to tell this painful part of their stories, but I am honored to be the platform.

Although the styles of writing and lengths of stories are different and this may look like raw data, it is not. Each and every participant wrote their background information concisely, and they can tell their stories far better than I can. This eliminated my fear of watering down what the participants said or seeming to be too harsh by readers because I am trying to stay true to the essence of how the participants told their stories. Therefore, I am ethically comfortable with stepping back, placing the participants in the center of this arena, and giving them an amplifier. 


\section{Danya}

Danya is a 50-year-old Black woman, a mother of four, and a resident of San Francisco, CA. Danya is a very loving person whom is very concerned with her community's condition. I have known Danya for over 25 years from public housing, incarceration and now in recovery. Over the past four years, Danya has been a strong supporter of the non-profit I founded. She is a natural born therapist because she has the innate ability to help people think rationally during times of need. Therefore, the value of her presence in my life is immeasurable. The following is Danya's recollection of her path into and out of the cycles of addiction and recidivism.

Danya: After I had experienced traumatic events in my childhood such as sexual, physical, and emotional abuse, along with the murder of my stepfather, I began to act out in school and eventually landed in juvenile. I got into a relationship that was abusive and became a teenage mother. Later on at 16, I got hooked on crack cocaine and life went downhill from there. I lost my children, and I began a life of crime through prostitution. I continued this for about 7 years until I caught a very serious case of someone else's and realized that all my children were away from me and in the child welfare system. I decided to go into recovery from jail and get my life together because I was tired. After being stabilized in my recovery, I decided I wanted to be more in life and decided to go to school and get an education. I had no skills, but I reached out to City College, and I found a program that worked for me. I completed the Community Health Outreach Worker program and got a certificate and also received an AA in Health Sciences.

Danya is currently a Master's of Psychology student, and she is due to graduate this year. She is working full-time as a Community Advocate and volunteers her time on a regular basis for the benefit of her community. Danya is very concerned with the 
violence in her community, particularly against young Black males, and it is her desire to use her degree in Psychology to promote healing on the behalf of this population.

\section{Zenith}

Zenith is a 54-year-old Black woman, a mother of one daughter, and a resident of the San Francisco East Bay. Zenith is extremely wise and thoughtful, every word that comes from her mouth is spoken slowly with emphasis behind it, almost preacher-style. She makes you want to listen; somehow her presence commands attention. Zenith has an excellent sense of humor with a smile to die for. I have known Zenith since I was a teenager. She is a very spiritual woman with a great deal of faith as well as the Gift of Encouragement. Although I assist Zenith academically from time to time, I don't consider it work because she is my friend. The following is Zenith's recollection of her path into and out of the cycle of addiction and recidivism.

Zenith: My path to incarceration began when I started experimenting with crack cocaine with my family and friends then strangers who I shared the common ground of crack with. I then became introduced to a prisoner whom I started dating who showed me how to hustle [when he got out]. When he got incarcerated again, I began utilizing what he taught me to maintain the life of a crack addict...I robbed people, set people up, stole drugs from the dealers. Lied, cheated, stole from those close to me, manipulated who I could, sold my soul and anything else I could. I became the master mind behind a one-man crime band... The single most important moment that made me know I had to change my life is when I called home from prison to talk to my grandmother and she had passed the day before. I was brought to the funeral by an officer who allowed me to sit with the family for a while which I was grateful for. 30 days later I was sent to a halfway house 2 blocks from where I lived....I was able to go home on passes and spend time with my child who was now 10 years old. I was then faced to deal with the 
family home being sold because of the theft of money. I went out and got a job to help my mother secure the property. My parole officer kept me on parole longer because she overheard me arguing with my uncle about the situation, and she felt it was going to take me backwards. It pushed me forward.

Zenith is currently a community college student finishing up her last semester before she transfers to a 4-year university. Zenith has a history of serious health complications, which led her to be in a comatose state for a period of time, but this hasn't stopped her. She is maintaining passing grades at the community college level, and her ultimate goal is to obtain a Doctorate in Philosophy.

\section{Andrea}

Andrea is a 44-year-old Black mother. I'm not sure about the number of children she has. I met Andrea through providing services for formerly incarcerated women at a local community college. Initially, she was pursuing several certificates, but I challenged her to go further. After a couple of months, Andrea informed me that she was going to complete her Associate degree and transfer into a local university. The following is Andrea's recollection of her path into and out of the cycles of recidivism and addiction.

My life started to go array when I turned 13 years-old, which is around the time I started smoking marijuana and drinking. It was not long after that I started smoking crack and selling crack. I hung out with the street thugs to get the attention that I was not getting at home. Soon I dropped out of school to become a full fledge drug addict and dating drug dealers so that I could support my habit. My first arrest was when I was 16 years old and 1 got caught up in a raid in Sunnydale Projects where I was selling drugs at the time. I went to youth guidance center which is juvenile. I spent about a month... That did not detour me from a life of crime. I came straight out of juvenile and started using and selling 
drugs again. I was able to feed my habit without consequences until I turned 19 years old when things really turned for the worse. I started snatching purses and well after my successful 2 purse snatches that third time landed me incarcerated, which got me a three-year prison term. The single most important moment that made me realize that I needed to turn my life around is my kids. I did not want to be like my mother was to me and not be a part of my life/their lives but after years of turmoil battling my demons that's exactly what I had become an absent parent...I have been battling with my disease of addiction for over 34 years. I came to the realization that I had a problem years ago but that never stopped me from relapsing or partaking in criminal activities. I currently have close to three years clean what I am doing this time is I dealing with the mental health issues that I have and no longer ignoring them. I am surrounding myself with positive people.

Andrea was able to complete her Associate degree and get accepted in a local university. She kept a very heavy level of responsibilities on her plate: she worked two jobs, took classes at the university, and she still was taking classes at the community college to finish up on those several certificates she was pursuing. I tried to talk her out of such a strenuous schedule, but she did what she wanted to do. The last time I heard from her, she was experiencing a hardship. Unfortunately, I have not heard from her since after multiple tries to get in touch with her. I pray she is okay.

\section{Regina}

Regina is a 55-year-old mother of three biological children. She curnently resides in the Midwest, where she moved after living in Northern California and the San Francisco East Bay Area. She is a very spiritual woman that will stop what she is doing and pray for others at a moment's notice. I was introduced to Regina by one of my 
classmates, and we have been talking on the phone with one another from time to time ever since.

My life took an early turn for the wrong things of life...My father was a drug dealer, and I daily witnessed his criminal activities when I would visit him for the summer. At times he even had me to count and package his Valium pills for distribution. In retrospect I can see why it was so easy to get caught up in the justice system, without intervention it was just a matter of time. I was around people in the justice system from the very beginning so my thinking about law enforcement and authority was distorted early in life. In high school, I met a friend sophomore year and I believe that access and exposure to her is where my perceptions about law enforcement and authority were even more persuaded. I smoked marijuana and drank alcohol almost daily by the time I was 16 . I had too much freedom and access to the seedier side of life that most adults, let alone children, ever come to know. As a matter of fact, where I came from it was almost a badge of honor to have been arrested and to have a criminal record. What eventually happened is that I got addicted to crack cocaine in the early 80 's during my early 20 's. ... Fraud and larceny were commonplace...I finally got arrested, incarcerated and released with the contingency that I pay checks off. Long story short, I failed to do so... Then my mother passed away... The police came and informed me that I had 58 warrants for check fraud... The first night that they told us to go into our 2-person cell for the night and I heard that steel door slam shut. It was one of the lowest moments of my life. I will never, ever, forget that sound. The sound of the door telling you that you are powerless. Telling you that you have no control over your life at that moment. Telling you that other people have charge over you and you have lost your freedom and come or go. Telling you that you will not see your children. Telling you that will not be getting high anytime soon. Telling you that you have made a complete disaster of the life that God gave to you. Telling you that there will be more of this without personal change. It was a moment that I will never forget. It still took three additional years for me to take a step toward change.

Regina has since earned a Bachelor's in Theology. She would like to one day return to school and earn a Drug and Alcohol Studies certificate. She is extremely passionate about helping people who are downtrodden. Regina's passion matches her 
abilities because she is highly skilled in cheering people up and giving sound advice. I know this because she has done it for me.

\section{Seline}

Seline is a 63-year old Black woman with no children, and she is a resident of the San Francisco Bay Area. Seline is an extremely kind and hard working woman. As an elder that I have a great deal of respect for, it is hard to imagine that Seline was once a drug addict. Her demeanor is very graceful. I met Seline two years ago while she was volunteering her time at the local community college, working with formerly incarcerated women that were pursuing a higher education. I work with the same group of women. I admired her work ethic, and we began working together.

My life took a turn at age 13 when I began drinking and smoking. I wanted so badly to be an adult and have the freedom to make my own grown up decisions. I continued learning how to become an alcoholic and at the age of 25,1 began hanging out in the night clubs. Soon after I learned how to smoke crack. At this point it was just a matter of time, it was not long before loss of employment and homelessness had me from pillar to post and to jail. The single most important moment came when I realized that I was crying all the time, even when watching a comedy. I would burst into tears at the most inopportune time, during the day at work, at play, cleaning the house or doing anything else. I realized that something was wrong and got myself to the doctor. This began my road to recovery and going back to school to achieve my educational dreams.

Since returning to school Seline has earned a Bachelor's in Liberal Studies with an emphasis in Biology. The community college she has been volunteering for is seeking to hire her permanently; however, it hasn't happened yet. She is such an exceptional and loyal worker that I am going to try to beat the college to the punch. We are currently 
working together to determine ways to bring more women off the streets and into the college.

Collette

Collette is a 63-year-old Black woman, a mother of one daughter, and a resident of San Francisco, CA. Collette is a soft-spoken woman with an aura of wisdom that is released even while she is silent. I have provided educational mentorship services to Collette for the past two years, and I also assist her with getting her nonprofit paperwork off the ground.

Well it all started when as a young girl I was brought up in a home that was very religious and strict (Pentecostal) We were taught not to take part in the worldly part of life, for example no movies, no pants, no parties, no foul language, 5-7 days of services sometimes a week. This was ok until I started wondering what was so bad about the other side of the coin. I grew up following all the rules and limitations I had as a teen until I was 20 years old, and I started working and taking care of myself. I met some coworkers at work and we got along pretty well, so we decided to go out to a bar after work and have some drinks and etc. This was the beginning of my journey to incarceration because I was not used to clubbing or drinking. I was just so gullible and naive. This became a cycle of being loose and not caring about my Church background and it lead to the Drug scene and getting hook on Cocaine (snorting). It got to a point where I got fired from my job for not showing up. I eventually got another job but I continue to use Cocaine and heavy drinking so it was a revolving door for the jobs. I wasn't attending my Church and still living with my parents who eventually put me out for all the sinning I was doing. I finally met a naive man who became my investor in buying drugs for me, but that got old when he realized that he was getting broke supplying my drug needs. He wanted me to stop using, and I wasn't ready to stop, so I made up a deal that if we sold drugs we would take care of both of our needs (habit/money)... That idea took me down a dangerous path because I was using $24 \mathrm{hrs}$ a day and 365 days a year... I was arrested time after time for 
drug use and sales in and out for many years until I landed up in the big house (women's prison). I also had a baby while I was strung out and not caring for her, my parent was so ashamed and took her from me. This made me realize I needed to stop asap.

Collette is currently pursuing a certificate in Drug and Alcohol Studies, and she is scheduled to graduate next year. Just the other day, she was talking to me about going further in her education by getting an Associate degree and then transferring to a Bachelor program. I was elated. One of Collette's passions is ending hunger among homeless people, which she does as an avid member of her church. Collette is currently in the process of getting a nonprofit organization off the ground, so she can do it on a grander and more organized level.

The above-mentioned stories written by the participants have a lot in common: early exposure to drugs and alcohol, cocaine addiction, family separation and incarceration. However, despite all of the trauma, violence, abuse, and bouts with addiction experienced by this research study's participants, all of us managed to navigate our way through it and secure a seat in a postsecondary classroom. Not only did we secure a seat, we managed to persist and thrive in a higher learning environment.

\section{Data Collection}

The following is a breakdown of how the data was collected over a six-week period. During week one, a brief survey was administered to participants to verify eligibility and collect demographic information (see appendix A). After the participants filled out the demographic survey and their eligibility for participation was verified, the 
participants, including myself, were asked to respond to the week one writing prompt. The participants were instructed to write for no more than 30 minutes. Each week over a period of six weeks, the participants responded to a different writing prompt through email. I have included the verbiage for each writing prompt that was delivered over the six-week period (see Appendix B).

During the first year of my doctoral studies, I conducted a pilot research project. I asked FIBW, who have taken on the role of community advocates and scholars, to participate in a 10-minute free write session to define Black Girl Magic and how it applies to them, and I conducted a focus group afterwards in regards to their experiences with P-12 and postsecondary education. I thought the focus group would bring forth the most valuable information; however, it was quite the contrary. The free-write session yielded a powerful belief system and set of self-affirmations that I was nowhere near prepared for. This is why I chose writing responses versus oral responses. The writing prompt topics are designed to highlight resilience, coping strategies and unique needs of the participants in order to identify the social/emotional and academic characteristics of the participants. All of the responses were typewritten, leaving no room for misunderstanding or misinterpretation of the data due to illegible handwriting.

The sample for this research study is represented by 7 FIBW women, including myself. All of the participants were recruited by word of mouth. I have access to FIBW because they are my peers, and I work with formerly incarcerated women at a local community college. The participant eligibility criteria are as follows: participants are all 
ages 18 and over, and they are all FIBW who have managed to successfully make the transition from incarceration to a postsecondary education. Postsecondary education is defined as any level of education that is at a college level, including certificate courses. The remainder of the inclusion criteria are as follows: participants should have been arrested at least three times or have done a year or more of time incarcerated in their lives; participants should identify as Black or African American; all participants should identify as females or have been born a female. Participants must be in good standing with their educational program post-incarceration or have completed an educational program post-incarceration.

\section{Data Analysis}

While conducting research utilizing the narrative inquiry approach, a researcher works to find theory within the participants' stories, keeping the stories intact in order to preserve their true meaning. In opposition to other qualitative approaches, such as but not limited to grounded theory, which breaks down stories into codes, the narrative inquiry approach employs the entire story for the unit of analysis (Lal, Suto \& Ungar: 2012). After the responses were submitted, I holistically read and then analytically re-read the responses. Holistically is being defined as utilizing my life experience, my imagination about what exactly the participants were experiencing, and my knowledge of the topics being written about. Analytically is being defined as reading while looking for common themes, plots and outliers. I then wrote a data summary for each writing prompt, which totaled seven responses. 
The holistic data memos were written about the individual stories reflecting upon how I was impacted by the stories, utilizing my imagination, expertise, life experience and allowing myself to feel the data. The analytical data memos that were written identified emerging themes, patterns and congruencies, which gave me the foundation to talk across the stories. Six critical colleagues, a professor and five students in my doctoral program, were utilized to each read one writing prompt each. This entailed us having a discussion about what they read and identifying any emerging themes that came forward for them. I in turn created typewritten responses from their input. I also searched my book From Crack to College and Vice Versa (Jones, 2013) for answers to the writing prompts and to find data that may be congruent with the other participants' stories and emerging themes.

The purpose of rereading my own book was to revisit and highlight a space where I was unafraid to express my inner voice, utmost fears, disappointments, guilt and methods of triumph. I am no longer in that space, but I was willing to revisit it for the purposes of communicating about a world that many have not been privileged to live through. I wanted to do my best to accurately represent the struggles I faced and continuously face as a FIBW, and attempting to do so under my curnent status would be a farce. I needed to include the voice I used when I was reaching out for help. This process was repeated until all of the writing prompts have been subjected to the above-mentioned steps. 
In order to gain a deeper understanding of how I interpreted the data, I reread my holistic and analytical memos, paying attention to the emerging characteristics. Initially, several characteristics emerged from the data, which were collapsed into groups due to similarities, ranked for importance and given titles, taking into consideration the participants' responses, my personal experience, and the input of my critical colleagues. After this rigorous process, one overarching concept, the Strong Black Woman schema, and three characteristics emerged from the data: Strong Advocacy Skills, Socially Resourceful/Excellent Hustler, and Spiritually Connected.

Finally, I determined the convergences among the data and chose narratives, descriptive analyses, and profound statements that helped me to describe the social/emotional and academic characteristics of the participants that are sought to be understood under the research question. This gave me the foundation to write a congruently connected and engaging research story that captured the depth of the strengths, struggles, and beauty of FIBW who have managed to make the transformation from prisoners/inmates to scholars. Utilizing a collaborative narrative inquiry method enabled me to gain insight into the complex dynamics involved with being a FIBW. The stories, as revealed in the next chapter, unraveled the magnitude of trauma experienced from childhood through adulthood and how we persevered and pushed forward. 


\section{Chapter Four: The Findings}

This chapter focuses on the research participants' characteristics that emerged from the data with a special concentration given to characteristics that assisted with the engagement in a postsecondary learning environment. Three characteristics emerged from the data: Strong Advocacy Skills, Socially Resourceful/Excellent Hustler, and

Spiritually Connected. All but one of the participants embraced the title of being a SBW, and all of the participants gave responses that fell within the guidelines of the tenets involved with the SBW schema.

\section{Strong Advocacy Skills}

The ability to courageously advocate for oneself is one of the tenets of the SBW schema (Watson \& Hunters, 2016). Even though this is a tenet of the SBW schema, the advocacy component deserved to be fleshed out into a theme of its own because it resurfaced throughout the data. The act of being an excellent caregiver, which is also a tenet of the SBW schema (Abrams, et al., 2014; Beauboeuf \& Lafontant, 2007; Davis, 2015; Donovan \& West, 2015; Watson \& Hunters, 2016), may also require advocacy skills.

Advocacy is often seen as an act that is conducted by communicating; however, for the purposes of this study advocacy is defined as communicative measures and/or actions that are taken for the benefit of self and others. Thus, not only are the participants 
in this study, including myself strong self-advocates, but we are also strong advocates for others, including our communities and other members of society that are in need of our expertise and unique way of caring for others. As a result of these findings, the Strong Advocacy Skills characteristic has two subthemes: Self-Advocacy and Community Advocacy. Both sub-themes, Self-Advocacy and Community Advocacy, may require the utilization of resistance capital.

\section{Self-Advocacy}

The term Self-Advocacy is defined as the participants' abilities to speak up for themselves, as well as get their needs met through their actions. All of the study participants were asked if they were ever exposed to discrimination due to their racial or gender status in an educational setting. A description for discrimination was not given. None of the participants reported being discriminated against because of gender. Two of the seven participants reported not being subjected to any type of discrimination in an academic setting. Four of the participants, including myself, reported facing discrimination due to race in an academic setting, and one of the participants didn't fully answer the question; instead she elaborated upon her ability to navigate through it.

The following is an excerpt given by the one participant who chose to talk about her ability to navigate through the process instead of what she may or may not have been subjected to on a discriminatory level. 
Regina: I had to think about this question for a while before I could approach it with all honesty and truth. If anything, and if there were ever discriminations made or directed toward me, they were to my benefit. There were reverse situations in my case because of my approach to school. And also because I always managed to develop closer, more personal relationships with my instructors.

As mentioned previously, two of the participants, the elders in the study whom both happened to be 63-years-old, reported not being subjected to racial or gender discrimination of any kind in their academic endeavors.

Seline: As a Black woman pursing higher education, I am unaware of encountering racial, class, or gender discrimination from instructors, staff members or fellow students. Quite the contrary everyone that I encountered was more than willing to see me succeed.

Collette: As a Black woman pursuing my higher education, I have not experienced any racial or gender discrimination from any staff/student.

The comments from the elders in the study were hard for me to fathom. I wanted to go back and ask them more but it felt somewhat disrespectful to question their wisdom and perception. Instead, I decided to honor their responses. Perhaps they have mastered the ability to self-advocate to the point that any and all adverse discriminatory experiences are minimized through their perception. However, I have to say I really don't know.

Four of us that participated in this study had elaborate stories that we told of selfperceived racial discriminatory practices of faculty members on college and university campuses. 
Andrea: As a black woman pursuing a higher education, when I was attending Heald College in Hayward at times I felt as if I was being discriminated against based on my race by two professors. One was by an affluent teacher when I was attempting to test out of her Microsoft Word class and I only missed one question on the test and she denied me my request to test out of the class. Since it was a requirement to either test out or take the class, I had to take the entire class. Another time was when a male professor assigned a group project and the members of my team were slackers and not doing their part. I brought this to the teacher's attention and he said that "you cannot change your team and you have to accept whatever grade that you get", and he refused my request to do the project individually. At the time I was trying to maintain a 4.0 G.P.A. Unfortunately, because of this team project I received a B in the class. I coped with the discrimination by not giving up and dropping out but by trying even harder and complaining to the dean. When graduation time came and we were asked to fill out a survey as to how our experience was while in school needless to say I gave a negative review, stating what I had to go through with the two situations.

Zenith: I have experienced this especially within the last year. I know that I verbally took a stance by making a statement to this music teacher. When I first felt something negative reverberate in my ears from his words. It had an effect on me every Tuesday and Thursday. I found myself watching the clock. If I raised my hand, he would overlook me and pick either a man or someone from his culture. Not only was I green it took more explanation and visual explanation for me to understand music theory. They do not have tutors, so there was no help. I felt that he was insulting me when he would suggest that I should drop out or when he told me I should ask my classmate who was a special needs kid for help. When I would ask him how I was doing, he said I don't know because I don't if you're going to get worse. I was always the last one taking the test. He would have conversations while I was taking the test or he would cut the test short and say it has been an hour. I became angry enough to push myself even harder but I also stop taking care of myself physically. The day before midterms I started feeling ill so I went to have myself checked by a doctor. I was ordered by the doctor to take a few days off and rest. Well that may work when you have job, but it doesn't work when you are a student because you still must turn in the assignments. In my case, it was take the test and I was exhausted mentally and physically by this teacher that I could not get grounded. When I approached the teacher with the medical documents he did the usual which was try to brush me off. I said I need to stop and I revealed the medical problem that I was having and the stress that I was under in his class. He never said anything after that. It was 
ironic that the music report I had to turn in was about a song called "My Right" and it spoke about the discrimination in the schools by the teachers, on jobs, and other places. I had the opportunity to share that song with the very person that did it to me. In this case because it worked itself out in the end I did not report him. It was his intention to make it appear that I was angry toward him if I would have allowed my emotions to take control. Instead he was forced to see this is the way you treat people with a disability and this is the discrimination tactics that you use as a daily weapon to oppress the people you don't care for. Karma came back to visit, and he had to answer the door. I have seen him many days since then and it is now "hello".

Danya: Going into my Master's program I was given a racist counselor whom is also the chair of my program. She did everything in her power to shoot me down, even in front of my other classmates. She was very condescending towards me when I would raise my hand to ask questions and she was always culturally inappropriate, although they taught cultural competencies, which I felt was not suitable. When I told her my life history in one of our sessions, she replied "well since you have such a colorful past, let's see if you can even be licensed as a therapist". She has accused me of plagiarism, turning in past work from another class, and all this was done in the presence of my other classmates. She had me so furious I was ready to make her a shit pie, as Viola Davis did in The Help. She deserved it. After so many months of calling her in for mediation, I was just done with her. She always fills me with anxiety. At the last meeting I had to tell her, "Nobody went to school for me, nobody wrote my papers, I did this! And I will no longer let you have my energy." She tried her best to make me crumble, but I am still here!

Marilyn: It seems the higher up I go, the more I am subjected to discriminating factors educationally. The curricula that is supposed to be about social justice is extremely depressing and deficit-based. Often instructors who claim they are about social justice and equity are only prepared to work with students who think like them. Diversity is not just skin color; it is also choices. One day when I was in my class, an instructor started explaining how be could be there for the students due a natural disaster. I disputed that fact because of how I was treated. I was hoarse at the time, so I couldn't raise my voice, so I whispered my concerns with him. The teacher, a grown man ass white man, broke out in tears and said he felt "attacked". White fragility AKA white tears is utilized often as a weapon. Another day, a white female teacher told me when she heard there were so many Black students in her class she was "scared". Both of these occurrences happened during a doctorate program. I don't cope well in these types of situations. I get very depressed and angry, but somehow I am able to make it back to school. 
The stories in regards to self-perceived discriminatory practices of college and university faculty were the most elaborate stories given. Danya contemplated utilizing tactics she saw in the fictitious movie "The Help", which depicts the 1960's. It's unfortunate that a highly educated Black student would have stoop to thinking of baking a shit pie in 2018. I can only imagine the turmoil in her mind. I can relate because of several disturbing interactions with professors and faculty. One example is the abovementioned white male instructor who was elaborating to the class about the amount of support he was willing to give in the face of a natural disaster, yet it was not given to me. I had previously called him and told him I was suffering health wise due to the smoke from the fires, and all he could do was express ways that I could deliver academically despite what I was going through. Ironically, I was just exposed to Wun's (2016) "afterlife of slavery" concept one semester before this incident. As mentioned previously, the "afterlife of slavery" is defined as a free woman being treated as a slave woman, which had to work no matter what ailed her. My mind was in turmoil, knowing this concept was coming to pass in my own life. When I spoke to this teacher about this in person during class, he literally started crying because of my words, which by the way were delivered in a whisper. He didn't know the tears I had already cried privately though, so I stood firm.

The ability to not give up despite self-perceived racial discriminatory practices is a common attribute discovered among the responses given among the participants of this study. We shall not fold! This is also a tenet of the SBW Schema that was found during 
the literature review, which states that a SBW operates under a belief system that she has the ability to perform favorably despite the acts of oppression that consistently work in opposition to her state of mind (Donovan \& West, 2015). Performing favorably despite opposition can be viewed as a form of resistance. Although resistance capital is abundant among this sample population, resisting is a great deal of work. The ability to speak up for oneself is not always thought of as having agency or greeted with glee when it comes to Black women. It is often misunderstood, particularly in an academic setting based upon my experiences, but despite that the participants in this study have managed to do keep advocating for self.

In order to be a good self-advocate, one must be able to ask for help for themselves. For students, this may require sitting in the front of the class, joining study groups, going to office hours of college and university faculty members, and surrounding themselves with positive influences. That section of academic empowerment will be covered in the latter portion of this chapter under Socially Resourceful/Excellent Hustler. This portion of the self-advocacy section is focusing on the personal aspects of the participants' lives. Let it be duly noted that all of the participants of this study have managed to leave a lifestyle of drug addiction and recidivism. None of us could have conquered this without the help of others. All of us have managed to do so by putting our prides to the side and seeking help. This requires a great deal of humbleness and boldness at the same time. Everybody is not able to do it, and this is evident by the mass number of 
addicts who die premature deaths and don't ever come close to reaching their full potential.

Black women are often required to live up to a strong and somewhat mythological character by society, their communities, and their families, which leads to unrealistic selfexpectations. Thus, the act of asking for help is not always followed up with a compassionate response. Danya talks about her experiences asking for help in the following response:

Danya: Although at times I am exhausted and tired, I don't express it, and when I do I am often not believed.

I spoke to this challenge in my following writing response:

Marilyn: Calling in sick from life is not allowed. I must perform regardless. It doesn't matter what I've been through or what I am going through. I must perform, so I put on my Warrior Queen mask ever so tightly when necessary, which is often. I must be able to live with injustices, premature deaths, men not living up to their duties, white folks' ignorance, and some more shit. I'm too proud to say "Boss, I'm tired!", but God knows I am. I have 6 children (5 adults and 1 minor) and even they don't understand what it takes to comfort me. I can cry out to them over the phone, and I can tell that they are uncomfortable with it because if I attempt to go into my weak or shall I say feminine side they easily can end the conversation. Even though I may initiate the ending of a conversation by saying something like "I need to get off the phone" while I am crying, they easily end the conversation and never bring back up the fact that I may be in a weak state of mind when we talk again.

Regardless to the lack of compassion and understanding the participants of this study are often subjected to, we have all found a way to speak up for ourselves and push forward in our personal lives and academically. Much of this is due to our ability to advocate for ourselves no matter how ill-met our advocacy skills are received and the 
abundantly present resistance capital we have access to (Yosso, 2005) that our ancestors so graciously handed down to us.

\section{Community Advocacy}

For the purposes of this study, community advocacy is being defined as the want and ability to advocate for and correct the disparities that exist within communities. Being drawn to acts of community advocacy speaks to our desire to be excellent caregivers, another tenet of the SBW schema (Abrams, Maxwell \& Belgrave, 2014; Beauboeuf \& Lafontant, 2007; Davis, 2015; Donovan \& West, 2015; Watson \& Hunters, 2016), and our need to utilize the resistance capital that has been extraordinarily afforded to us (Yosso, 2005). This high level of resistance capital and desires to be great supporters in the community was communicated by all of the participants, including myself, throughout the responses.

Regina: [Being a SBW] affects me positively in the aspect that people who are in less fortunate situations are sometimes more prone to trust that I am okay. The broken ones that society has thrown away in all races and cultures. I guess they relate to black women because they know that like them, we too have not gotten a fair shake.

Marilyn: I am positively impacted by my title as a strong Black woman because people needing me feeds my soul. When I am able to teach my people or when they come to me for advice, my womb is delighted.

Seline: The strong Black woman is required to sometimes put aside her feelings of what she may feel like doing and do what is best for her loved ones....The negative effects [of being a SBW] can sometimes include my own good mental health from self-imposed pressure to be successful in maintaining these attributes successfully. 
This desire to be supporters of the community is not only communicated by the participants, but most importantly it is also represented in actions. All of the participants have made career choices that are designed to assist the community. I have chosen to pursue a terminal degree in Educational Leadership because I found in my studies over the years that education and the lack thereof is a root cause of incarceration. Danya has chosen to pursue a Master degree in Psychology because she believes her community needs healing. Regina chose a degree in Theology because she has a desire to help others find God and help others find their divine calling in life. Seline is now in a career that enables her to help other formerly incarcerated women succeed academically. Collette has chosen to seek a certificate in Drug and Alcohol Counseling, so she can help others push passed their addictions and succeed in life. Andrea has chosen to pursue a Bachelor of Arts in Social Work, so she can assist others with moving past their challenges in life, and Zenith has chosen to pursue a Doctorate in Philosophy, so she can utilize the pain from her past to assist others with moving forward.

Having the ability to advocate for self and the community is a characteristic very prevalent among the participants of this study. This skill is necessary to get needs meet, battle disparities, and in some cases begin social movements. However, in some instances instead of this characteristic being seen as a positive trait being portrayed by a Black woman with a strong sense of agency it is met with intimidation, stereotyping and fear. This opposition can be very taxing on someone's soul who has the Gift of Advocacy. Nevertheless, it must be done. 


\section{Socially Resourceful/Excellent Hustler}

The definition of Socially Resourceful for the purposes of this research study is referring to a person that is bold enough to be seen and heard and displays a high level of capability to utilize the resources and support systems that can assist with their upward mobility. The act of being socially resourceful or hustling involves a skillset that utilizes a combination of two components of the CCWM, social and navigational capital (Yosso, 2005). In colloquial terms, this person would be referred to as a hustler. Hustler is a term that has positive and negative meanings. In some environments, such as criminal justice environments and other conservative areas, hustler may be a negative connotation. However, where I am from hustler is a gender-neutral term of endearment and admiration. It speaks to someone's ability to get their needs and sometimes wants met despite the odds against them. Two sub-themes emerged for this characteristic: The Hustle and Ability to Build Social Capital.

\section{The Hustle}

Excellent hustlers typically know how to "make a way out of no way", and their work ethic is admirable, a far cry from lazy. Juggling multiple roles and responsibilities may be required to fill the shoes of a hustler. A notion of having to be able to "do it all" and hold everything together was an attribute that was perceived to be expected of the participants, which coincides with the SBW schema's mastery of self-reliance (Abrams et al., 2014; Donovan \& West, 2015; Davis, 2015). The participants' responses below 
explain the high and overwhelming standards that Black women are held to in their quest to be self-reliant:

Regina: Most of us don't really recognize that we are Strong Black Women. We see society's take and view on what is successful and what is not. This thinking takes us away from the indisputable fact that WE ARE THE GLUE. We are the glue that holds black families together. We are there when our men walk away, leaving many of us left to hold everything together. Most of us are single with children. As little girls that was not our plan. Most of us dreamed of an idyllic life with a husband, children, a great career, lots of money and live "happily ever after". Maybe that's why people don't teach their children Fairy Tales anymore, lol. But seriously, most of the time a black woman is required to single-handedly raise her children, work, feed and clothe herself and the kids, educate herself, maintain her household and still wake up \& "face the world with a dazzling smile".

Collette: I believe that a strong Black woman has to hold everything together by herself (household, kids, job) and show no emotions about it. So I don't want that title placed on me. I'm don't consider myself a strong Black woman, I'm a Black woman who has emotions, feelings and just trying to get through everydày daily life and make a difference in someone's life.

Marilyn: She [a Black woman] is the backbone of the Black community. As a matter of fact, she is the backbone of this planet Earth. She is the glue that holds everything together. A strong Black woman is not allowed to be white folks' definition of feminine. No, she has to be strong like Maxine Waters and tell them, "You betta shoot straight!", strong like a man.

Although I self-identified as a SBW and seemingly embraced my perceived responsibilities of having to do it all and hold everything together, I clearly understand Collette's sentiments. Collette is an elder, and she has grown old enough to reject the notion of being a sheroe. Even though Collette rejects the SBW title for adequate reasons, and thus is an outlier, her response does express an attribute that is also a tenet of the 
SBW schema, the desire to have a positive impact on someone else's life (Donovan \& West, 2015; Davis, 2015; Abrams, Maxwell \& Belgrave, 2014; Watson \& Hunter, 2016; Beauboeuf \& Lafontant, 2007). Collette also has mastered the ability to engage in many endeavors. At the age of 63, she is currently engaged in many endeavors (going to school, starting a non-profit, and actively volunteering with her church). She truly meets the definition of an excellent hustler.

Another trait of an excellent hustler is the ability to "bounce back" after adversities. Hustlers don't allow setbacks to determine their future outcomes in life. This entire dissertation focuses on the "comeback" that all of the participants were able to engage in. The expectation to be able to overcome is something that not everyone mentioned but it was implied. Danya spells out this self-expectation below:

Danya: A strong black woman is an individual that overcome adversities and challenges by remaining resilient, a woman that is able to make a way out of no way with standard challenges that she is faced with in order to survive.

Danya's response aligns with the SBW woman schema tenet that says a SBW operates under a belief system that she has the ability to perform favorably despite the acts of oppression that consistently work in opposition to her state of mind (Donovan \& West, 2015). All of the responses in this category address the participants' beliefs of what is expected of Black women, particularly SBW. The responses and actions of the participants' highlight the perceived societal and self-expectations which dictate that Black women must be "a jack of all trades" while overcoming oppositional barriers at the 
same time. These expectations have given birth to actions and helped to mold the Socially Resourceful/Excellent Hustler characteristic among the participants.

\section{Ability to Build Social Capital}

All of the participants reported that being exposed to positive peers on and off campus was a mitigating factor that lead to their academic engagement and retention. Joining study and other extracurricular groups with like-minded students was also reported as strategies utilized by the participants in their efforts to do well academically. Although the factors above point to extrinsic causes, positive academic outcomes could not have happened without the participants' intrinsic abilities to build social capital and navigate through the process.

Regina: It was when I went to drug treatment that I knew I would go back to school. Half of my associates in the NA/AA Program were in school. I knew that I could do it because I had gotten clean and sober. Once I settled down in treatment, I saw how the counselors were helping us. I had always been the caregiver sort and going to school to be a drug counselor was where I knew I needed to be - and I knew that I would be good at it because I myself was an addict... Yes. I had trepidation because of my low self-esteem. Also, the whole math thing really had me anxious. But I went ahead and got started when I had about two years clean. I was thinking that the math would be one of the obstacles that I may not be able to overcome. Fortunately, I did well because of study groups, asking a whole lot of questions and working my butt off. I overcame my fears by walking thru them. I worked my math problems over and over and over until I got it. Algebra was a formidable foe for me, but I was able to master my lessons and ended up with an $\mathbf{A}$.

Danya: When returning to school I felt out of place and thought I was not as smart as others. I overcame these feelings by finding support on campus and reaching 
out to others I knew had an education. I started going to different resource programs on campus such as the African American Scholastic program at City College. I spoke of my fears and why I felt that way and that I needed guidance. I clicked up with people who are like-minded. I really enjoyed City College and thought of that campus as a family.

Collette: My wise decision to return to Church cleared my mind and gave me a new mindset to start working on my heart and body, then I realized that it was finally time to give back to all who had drug and alcohol problems and issues. I always wanted to give back but something would either block/stop me from starting the process. Yes, I was scared of the College process but I overcame my fear and stepped out on faith and start believing in myself for strength and courage. I called CCSF [Community College] Drug and Alcohol Certificate Program and connected with Waypass [program for previously incarcerated students], and the rest is history. I am going on my 2 nd semester and keeping my focus on passing and learning, so I may help others and give back to the community.

Marilyn: When I got home from prison, it took me almost 2 years to find a decent job. I got a job at UCSF as a data entry operator...I became a data entry operator for a national phone line that answered highly complex questions asked by professionals (doctors, social workers and allied health workers) in regard to their HIV/AIDS patients. After I was hired, I began communicating with my coworkers, medical doctors and pharmacists as a part of my duties. Before I got the job, I used to think highly educated people were special in some way, but I was started to realize they were just human beings. My coworkers began to teach me about HIV/AIDS treatment issues. They were great teachers, and I liked learning. After a few months, my coworkers and the project manager would tell me that I should go to college. They began saying it more and more. One day, one of my co-workers [a medical doctor] asked my opinion about something. After we talked, I started thinking if she needs my opinion maybe I am smart enough to go to college. So, I enrolled in one class to see if I would fit in, and the rest is history.

The above-mentioned responses, display the participants' abilities to build social capital on and off campus and the impact they perceived this had on their academic 
endeavors. Ironically, two of us, Collette and myself, described the process of socializing and navigating through the transitional process of college into four words "the rest is history". Possibly, the process of transforming from a prisoner to a scholar was too complex to elaborate upon, particularly while we are still both students, or perhaps the word history represents that we did what we had to do, and it worked out fine, moving right along.

All of the participants of this study were able to navigate away from dismai circumstances to positive environments. Not only were we able to transition into the positive environment, we found a way to utilize the social resources that were there. That is the true definition of excellent hustling. The participants already had the social and navigational skills necessary to succeed academically prior to coming to college. Although addicts do not spend their time wisely and often make foolish decisions, they have mastered the art of getting their needs met. This is not accomplished with a closed mouth or without utilizing the assistance of others. The mere act of surviving as an addict sometimes requires talking yourself out of some very dangerous situations. Therefore, speaking up and working the crowd is nothing new to the participants of this study. The participants have all found a way to transfer and funnel the skills that were learned in the streets in another direction. 


\section{Spiritually Connected}

Aspirational Capital is another form of capital that is highlighted in Yosso's

CCWM. Aspirational capital is defined by students of color's abilities to have hopes and dreams despite oppressive factors and situations in their lives (Yosso, 2005). Yosso failed to address the source of aspirational capital, and thus this makes the model woefully incomplete. In response to Kozol's book Savage Inequalitites (1991), researchers that attempted to utilize the CCWM to gage the capital in their community found the CCWM to be incomplete because they were not able to include or analyze what they experienced as "spiritual capital" (Farmer-Hinton, Lewis, Patton, \& Rivers, 2013).

In an academic setting, the concept of spirituality, divine intervention and miracles are hard to explain. It is no wonder why Yosso left it out of the CCWM. It was my desire to leave it out as well, but the participants made it evident through their responses that they had an abundance of spiritual capital. Thus, in my attempt to truly capture the characteristics of FIBW that made the transition to a postsecondary college student, spirituality had to be addressed.

For the purposes of this study, the definition of spirituality given by StantonTindall et. al. (2013) has been adapted, "[it is] a private, individual-level concept that is characterized by perceptions, beliefs, and feelings about a sacred or divine power, universal spirit or ultimate purpose" [and it is a] "sense of existential well-being which has been referred to as an understanding or belief in the meaningfulness of one's life" (p.2). Under the adaptation of this above-mentioned definition of spirituality, there are 
two categories that encompass the Spiritually Connected emerging characteristic: Existential Purpose and But God.

\section{Existential Purpose}

The belief that one's life has been given a purpose or the need to fulfill selfperceived purposes in life were present throughout the participants' responses. Every participant has managed to find reasons for their existential purposes in life. These reasons ranged from fulfilling their self-perceived purposes as mothers, being able to improve lives of individuals, and being able to create change in their communities. It is ironic how all of the participants in this study measured meaning in their lives by the way they can provide for others, which is in direct alignment with the SBW schema (Abrams, et al., 2014; Beauboeuf \& Lafontant, 2007; Davis, 2015; Donovan \& West, 2015; Watson \& Hunters, 2016).

The desire to fulfill their purpose as mothers was found to be an aspiring factor that enabled the participants to initiate their comebacks, as mentioned previously. Andrea expresses her desire to fulfill her purpose as a mom in depth.

Andrea: What made me overcome the life of addiction, incarceration and escape death is my drive and need to become a better mother, friend, and citizen. My children I must say are my number one motivators because I really want to be a part of their lives and be a mother that they can be proud of. As well as a mother they can come to in time of need and I cannot be that person if I am incarcerated and actively using drugs. It's my motivation and goal orientated personality that allowed me to overcome my addiction and a life of criminal behaviors. I believe that I can do anything that I set my mind on no matter how challenging it may be. 
Going back to school so late in life is challenging because I am usually the oldest person in my classes and sometimes I feel intimidated because I think on how I wasted my youth on non-sense and criminal activities but when I get these feelings I try even harder and push myself even more.

Although the participants expressed that their desire to be better mothers was a source of aspiration for changing their lives, it should be noted that wanting to be in a position to help community members and the community as a whole was also held in high regard. The act of becoming educated was expressed a means to be able to better serve the community. Thus, becoming educated was perceived as a strategy to help fulfill their purpose in life, caring for others.

Danya: I have been through so many traumas in my lie and I have let them control me. All the pain that I endured in my younger years ran me into drugs and bad relationships. I was tired of always feeling depressed and unhappy. I had a child when I started using drugs that ended up in the child welfare system, and I had two more children while in my addiction who eventually were taken by the state. I knew I didn't want to be a drug addict when my children became older, so I knew I had to do more with my life. I pursued getting an education to better my life for myself and my children. I have a lot of friends that didn't make it and some who are still in their addiction. I do this work for them, to go back and save my people. I know how hard it is to shake addiction, so for this I want to do this work to help others overcome.

Collette: I use my life now to help others who are not ready for change or rehab. They can see the change in my life and can see that it is possible...My wise decision to return to Church cleared my mind and gave me a new mindset to start working on my heart and body, then I realized it was finally time to give back to all who had drug and alcohol problems and issues. I always wanted to give back but something would either block/stop me from starting the process. 
Zenith: I desired to want to be better so I could help others who had fallen victim to this new assault on people of color by the poison [crack cocaine] that was deliberately placed in our community.

Marilyn: I don't know how I am able to do that [deal with the discrimination at school without dropping out] other than God must have a special purpose for my life. I also don't want to let the people that are coming behind me down. I guess you can say I am a sacrifice. Not in a pitiful way though. This sacrificial student is kicking down doors and raising ceilings. I am a fighter. Fighters get beat up some time. It's part of my job description.

All of these responses have one thing in common; all of us have found a way to turn our pain into our purpose.

\section{But God}

In the Black community, there is a phrase that is used to reflect upon the awesomeness and abilities of God, "But God". The word God is mentioned throughout many of the responses consistently, pointing towards God was in the midst of it all. Everything is not explainable, but I will do my best. There is a point in life when things get so bad that there is no hope in sight, so many of us have to find hope in the unseen. The notion that there is a strong Force, Advocator, and Protector that can be utilized during traumatic times is sometimes the only hope left, especially when engulfed in the cycle of addiction and recidivism. The participants humbly expressed an overwhelming sentiment of gratitude to God for many deeds, such as but not limited to: protection during dangerous times, getting off drugs, making the choice to go to school, and being able to remain in school. 
Zenith: I know beyond a shadow of a doubt that it was God who kept me and guided me through the life of addiction and incarceration. I have my grandmother to thank for that. She was diligent in making sure that I knew who God was and why he was important in life. She did not send us to church she took my sister and I to church every Sunday. I also have my great grandparents who came from Texas every six months to visit. My great grandfather was a deacon and every Sunday before breakfast we were literally down on our knees while he headed the morning prayer. When I became addicted to drugs which led to incarceration among other things, I would always recite the only scripture I could remember at the time. "Greater is He that is in me, than he that is in the world." It was always my prayer to God to please don't let me die this way. I never forgot God during those dark times and can truly see how prison helped preserve my life so that I could turn things around with God's help.

Regina: Without a doubt I know that I know that I know that it was the Lord, my Lord and Savior, Jesus Christ who was on my side. When I look back over my life, I can see the hand of God from the beginning to this very day. God has a plan for every life, but He gave us all free will. He gives us the choice to choose between Him and the world. When I began to make my own choices, I chose the world. Even so, God was and is merciful, and He gave me another chance to choose Him - which is to choose life... My journey as crazy as it was, taught me skills both in school and in life that molded me. Hard times produce patience and endurance. Pain motivates. Jail and prison produce courage. These are some of the main qualities needed to get through school...and life. These experiences and my background give me more to offer than just the benefits of an education. They give me a bonafide degree from the School of Hard Knocks. Combine all these things with the Love and Grace of God and that makes for true and lasting healing for myself, those that I work with and everyone that I encounter.

Collette: I believe that this is what saved me: I always was a Spiritual Christian person of faith who believe that I'm connected to a power that is higher than I. I'm also very family oriented which triggers my happiness and sense of belonging. I believe my mind-set has always been positive since I was a young teen, when I was in my mess and on drugs and incarcerated I always prayed and ask my Supreme Being (God) to take this bad life and turn it around for the good. He did just what I ask him to do... 
Marilyn: When I paroled the last time (which was the $5^{\text {th }}$ time), I went right back to the crack pipe. However, during the last two weeks of my addiction, I began to pray differently. I was truly tired, but I just couldn't seem to do anything right. One day I asked myself, "What do I really want God to do for me?" I then realized that what I wanted was to think differently. I asked God, "Please change the way I think." He heard my cry and opened my eyes. I was able to think clearly about what I was doing to myself from a more rational perspective. For example, one morning during this time period, I went outside. One of my crack cousins was outside, and she gave me some crack and a few dollars. Normally this would make me happy, but this particular time I told myself, "This is going to mess up my whole day" (Jones, 2013, p. 87)...On January 7, 1997, at approximately 3 a.m., I smashed my crack pipe (for the millionth time) and went to sleep. When I woke up that morning, I was crying and thanking God at the top of my voice. I didn't know what I was thanking God for at that time, but I am well aware today. I didn't touch a crack pipe for the next nine and a half years from that day. I don't know exactly what happened, but I do believe God was responsible and the transformation took place in my sleep (Jones, 2013, p. 91).

The following was the last weekly writing prompt that all of the participants, including myself responded to: There are many women who have had similar iife experiences as yourself and were unable to make the changes you have in their lives. Some of them are still engaged in the cycle of incarceration, drug addiction, and many are deceased. Previously we have asked you who or what has helped you become the woman you are today. However, please think deeply and try to embrace what is it about YOU (i.e. your personality, what you believe in, etc.) that helped you escape these outcomes in your life? (Appendix B).

For some reason, this writing prompt prompted the participants to talk about their belief in God opposed to self-qualities. I was looking for them to give descriptions of their strengths, including their personality. I sat down and tried to answer the question for 
myself, and I was unable to write a fluent response, so I decided to make a list of affirmations instead:

1) I am gifted.

2) I am brilliant.

3) I am a fighter.

4) I am blessed.

5) I am highly favored.

6) I am a miracle.

After writing my list as I examined it closer, I found that the last three answers on my list are who I am in position with God as well as speak to my belief in God. No matter how hard I tried to get away from this Spiritually Connected section, it kept coming back to me and revealing itself through the responses of the other participants, the memories of my own life, the act of writing holistic memos, and mentally processing everything. But God. 


\section{Chapter Five: Discussion and Implications}

This chapter will discuss the findings in Chapter Four, including the overarching concept of the SBW schema and the three emerging characteristics, which includes Strong Advocacy Skills, Socially Resourceful/Excellent Hustler and Spiritually Connected. Each section in the discussion will cover the existing literature and what this research study adds to the literature. Implications for future research and practices will be explored following the discussion of the sections. There are implications from this study that can impact several fields of profession; however, for the purposes of this dissertation the focus will be on the educational and criminal justice fields. Finally, the limitations for this research study will be highlighted followed up with a conclusion.

\section{Discussion}

\section{Overarching Concept: SBW Schema}

The SBW schema emerged from the data as an overarching, inescapable concept that has impacted the decision-making processes, self-expectations, and as a result characteristic development for the participants of this study. The literature reviewed for the SBW schema was primarily written for the purposes of exploring and/or exposing the poor health and wellness implications associated with the schema. It has been found that high levels of the SBW schema impedes Black women's abilities to share their emotions and/or be vulnerable (Davis, 2015), which is associated with stress, depression and other 
less than optimal mental and physical health outcomes (Davis, 2015, Donovan \& West, 2015, Watson \& Hunter, 2016).

Although it is not explicitly expressed, the importance and necessity of the SBW schema to the Black community is implied in the literature reviewed. However, what is missing from the literature is what the benefits of accepting the title or aiming to reach the title of a SBW are for Black women. The SBW schema works in sync with the participants' life goals, the desire to help and care for others, which is being directly pursued through their education and career choices.

Being in the position to help and be needed by others is seen as an asset and a form of success by the participants of this study. Thus, the selflessness involved with the SBW schema, which leads to poor physical and mental health outcomes is also pleasing to the soul. Helping others for the participants of this study can be further described as a form of spiritual nutrition. Though the body may be starving for love and attention, the spirit is fed. What may seem to be burdensome to some people because they do not have the ability nor understanding to be in tune with other's needs is seen as a blessing to be able to serve others for the participants of this study.

Gaining an insight about the SBW schema played a huge factor in answering the research question. The research question for this study is as follows: What are the social/emotional and academic characteristics of FIBW that have made the transformation from prisoner to scholar? The purpose of the research question is to gain 
an understanding of this population, an understanding that is virtually missing from the empirical data. One cannot fully understand a person's characteristics without gaining an understanding of their mindset. The intersectionality of FIBW is not completed with race and gender. Ways of thinking should also be factored in when attempting to explore intersectionality.

In all actuality, the SBW schema is a stereotype. According to Oxford Dictionary, a stereotype is "a widely held but fixed and oversimplified image or idea of a particular type of person or thing" (2019). Looking passed the negative connotations that come with the word stereotype, the definition is suiting. The unfairness associated with being expected to live up to the SBW image is highly visible through the data collected in this study. Nevertheless, the SBW schema must be accepted because it is just as present in the air for many of us as oxygen is. It's as if when we took our first breath upon exiting our mothers' the wombs at the most fragile point of our lives, there was a presence in the air whispering, "Be strong Black girl, be strong", while working its way through our nasal passages. It seems as if this is the moment when the Black baby girl starts practicing flexing her muscles. There is no way possible to separate out was is breathed in through the air for some of us. In colloquial terms, "it just is what it is." The prevalence of the SBW schema in many Black families and communities is insurmountable.

What is also just as prevalent is the necessity of the SBW schema. This way of thinking has been attributed to many movements in this country including, but not limited 
to: the Underground Railroad, the Civil Rights Movement, the Black Power movement, the Black Lives Matter movement, and the Me Too movement. Thus, the SBW schema is not only beneficial to the Black community, it is beneficial to society as a whole. The research question of the day is: How can Black families, Black communities, academia and society learn to appreciate or show appreciation for the SBW to the point that she can relax enough to appreciate and/or care for herself holistically?

\section{Strong Advocacy Skills}

Strong Advocacy Skills is one of the three characteristics that emerged from the data collected for this study. There were two sub-themes for this characteristic: Selfadvocacy and Community Advocacy. The communicative abilities of Black women to speak up in defense of themselves is highlighted in the SBW schema literature (Watson \& Hunters, 2016). Although this ability that many Black women have to speak up for themselves should be seen as a strength, this skillset is often ill-met and perceived by some people as the stereotypical angry Black women (Lewis, Mendenhall, Harwood, \& Huntt, 2013). The Gift of Advocacy that is demonstrated on behalf of self and the community among Black women is a very misunderstood talent.

The community advocacy component is not directly named in the literature, but it is implied. Another tenet of the SBW schema is the desire to be an excellent caregiver (Abrams, et al., 2014; Beauboeuf \& Lafontant, 2007; Davis, 2015; Donovan \& West, 2015; Watson \& Hunter, 2016). Heiderman (2016a) found that the "culture of giving 
back", a philanthropic ideology, was extremely prominent among the participants of a study that was conducted with predominantly FIBW. Although it may be possible, it is hard to give back short of giving money without displaying advocacy skills. Caregiving and advocacy work hand-in-hand.

This research study adds the perceptions of FIBW that have managed to make a way out of no way to the empirical literature in regards to how their extraordinary Gift of Advocacy is executed and received by academia. This research also exposes how some faculty from educational programs, even those that are supposedly designed to promote social justice and equity, are not equipped to handle nor appreciate the strength of SBW.

\section{Socially Resourceful/Excellent Hustler}

The second characteristic that emerged from the data was Socially Resourceful/ Excellent Hustler. This characteristic is a combination of social and navigational capital as defined in Yosso's CCWM (2005) with a street twist to it, which will be explained further. The Strong Advocacy Skills characteristic complements the Socially Resourceful/Excellent Hustler characteristic because without the ability to speak up a hustler goes unfed.

Yosso's CCWM (2005) was the theoretical model that came closest to describing the social and navigational capital that exists among students of color. However, this research study is not about students of color, it is about FIBW. Furthermore, the street experience and the knowledge obtained on the streets is not captured in the CCWM 
model. The CCWM does mention capital coming from the community, but this does not necessarily suggest that there is something to be learned from living a street life.

The criminal justice literature highlights the deficits that exists among the academic achievements of formerly incarcerated people and the promising impact the pursuance of a higher education can have on recidivism rates (Harlow, 2003; Vacca, 2006). Although Black women are a part of the correctional population these seminal papers focused on, Black women's uniqueness, gifts and talents are buried in the data. Furthermore, there is far more research on correctional populations and the impact of education than there is for formerly incarcerated populations, which suggests that researchers are more comfortable with identifying us as viable students while incarcerated than while free.

This research study adds another insight to the criminal justice literature because it adds the voices of FIBW as well as uncovers a skillset that works well with becoming educated that exists among this population. All of the participants didn't mention having any problems navigating through the process of asking for help, joining study groups, interacting with like-minded students, writing complaints, and doing whatever it took to transition into their roles as students and remain in school. The resourcefulness and hustle capabilities among the participants of this study remind me of what it takes for a Black woman to survive a street life. This research study suggests that the life experiences of the participants, including the trauma and the street life, has resulted in a set of survival skills that are useful for adult learners in a postsecondary setting 


\section{Spiritually Connected}

The Spiritually Connected characteristic emerged as a source for aspiration and hope among the participants. Two sub-themes were found to be present: Existential Purpose and But God. The literature suggests that there is a high level of spirituality in the Black community (Staton-Tindall, et al., 2013; Farmer-Hinton, et al., 2013). StatonTindall et al. found that existential well-being is extremely important for Black women and that spiritual components should be incorporated into assessments, mental health well-being and drug treatment strategies. Seeking spirituality has been linked to recovery from drug addiction (Staton-Tindall, et al., 2013; Narcotics Anonymous, 1984), and it was also linked to coping strategies and high levels of hope and aspiration among 206 Black single mothers in college (Lashley, 2014).

This research study further exposes how Yosso's CCWM (2005) is incomplete because it does not address the source of aspiration among students of color, which is a major blunder for Black women that have an abundance of spiritual capital. Metaphorically speaking, aspirational capital is the car and spiritual capital is the gas. This research study adds the spiritual perceptions of women that have thus far been ignored empirically, FIBW. Being spiritually connected emerged as the underlying intrinsic force behind the participants' aspirations, drive, hope, persistence, and faith.

The participants' belief in God was something that could not be ignored or overlooked. When trying to explain everything without including God, this paper was 
not cohesive. The participants in this study have managed to survive adverse childhoods, drug addiction and incarceration and still be sane enough to contend in a postsecondary educational setting. There was no other logical explanation. Thankfully, God was present in the responses to the degree that spirituality could not be ignored. The acknowledgement of God literally assisted with this paper coming to a close.

This dissertation only scratches the surface of the dangers that were faced and the emotions that followed for the participants in this study. Without the belief of Divine intervention, advocacy, and guidance, it is possible that many of the accomplishments, including this dissertation, would not have been achieved. There were many signs of hopelessness posted up in the lives of the participants in this study; nevertheless, the reliance upon mercy and grace prevailed.

The data suggests that the combination of the above mentioned intrinsic characteristics allowed the participants to succeed in an academic setting despite not because of structural systems of oppression, K-20 education and the criminal justice system. Too often programs that are designed to assist lead with a deficit-based model, which gives no value to previous life experiences and coping strategies that FIBW may have that can benefit their future. Instead the focus is on creating different individuals and undoing what has been done, which helps to minimize expertise that can be vital for FIBW's successful reintegration into academia and society. 


\section{Implications}

\section{Implications for Teaching and Learning}

The ability to advocate for oneself and others is a skillset that SBW have, which should be looked upon favorably. However, SBW's extraordinary abilities to advocate is often met with intimidation, fear and retribution in an academic setting. A pattern of discriminatory punishment at the hands of teachers, professors and school administrators starts during Black females' childhood (Annamma, et al., 2019; Blake, Butler, Lewis \& Darensbourg, 2011; Morris, 2016; Wun, 2016) and is followed up with resentment by Black female students as a response (Wun, 2016). This process begins early in many Black girls lives and continues on through the doctorate level as expressed in this study.

Educational leaders must develop and implement culturally affirming curricula and trainings that address cultural biases specifically for Black female students across the board (K-12, postsecondary, and graduate education) for teachers, professors and administrators. The biased difference between aggression and agency when it comes to the perceptions of academia for Black and non-Black female students should be addressed. Agency is a form of power. We need to feel powerful too. However, often when teachers and professors come into contact with a powerful Black woman, or girl for that matter, they are unable to grasp the power. Educational leaders should assure that the curricula that is created to train educators is adjusted to include the power that exists in the Black community, including the power of the Black community's secret weapon, SBW. It is time to change the perceptions regarding angry Black women and girls 
expressing themselves in school to Black women and girls utilizing their Gift of Advocacy.

This study also identifies the importance of being able to be in the presence of like-minded students. Therefore, educational leaders at community colleges and universities should create a space for FIBW to be in the presence of peers. Although educational leaders at the colleges and universities should initiate the process of creating the space, they should not fully take the lead. These programs should be led by formerly incarcerated people that also participate in the planning and development process. The following is a table that defines the needs of FIBW in an academic setting based on the emerging characteristics and the academic strategies that can be developed to fulfill these

\begin{tabular}{|c|c|c|c|c|}
\hline Characteristies & \multicolumn{2}{|r|}{ FIBW's Academic Needs } & \multicolumn{2}{|r|}{ Academic Fulfillment } \\
\hline $\begin{array}{l}\text { Strong Advocacy Skills } \\
\text { - Self } \\
\text { - Community } \\
\text { (Gift of Advocacy) }\end{array}$ & & $\begin{array}{l}\text { To be able to speak up for } \\
\text { oneself and not be feared for } \\
\text { exercising agency in an } \\
\text { academic setting. } \\
\text { Recognition that the ability } \\
\text { to advocate for self and } \\
\text { others is a strength. } \\
\text { Opportunities to cuitivate } \\
\text { this skillset. } \\
\text { To be able to help others. }\end{array}$ & $\begin{array}{l}\text { 3) } \\
\text { 4) }\end{array}$ & $\begin{array}{l}\text { Training for educational } \\
\text { leaders and faculty in } \\
\text { regards to FIBW's } \\
\text { communication style and } \\
\text { thorough screening of } \\
\text { potential faculty and } \\
\text { administrators for racial } \\
\text { biases. } \\
\text { Reframe the narrative } \\
\text { regarding Black females' } \\
\text { communication skills from } \\
\text { angry, defiant and } \\
\text { aggressive to having the } \\
\text { Gift of Advocacy. } \\
\text { Create debate training and } \\
\text { opportunities. } \\
\text { Create opportunities for } \\
\text { FIBW to engage in } \\
\text { philanthropy. }\end{array}$ \\
\hline $\begin{array}{l}\text { Socially } \\
\text { Resourceful/Excellent } \\
\text { Hustier } \\
\text { - The Hustle }\end{array}$ & & $\begin{array}{l}\text { Ability to fellowship with } \\
\text { like-minded students. } \\
\text { Access to various support } \\
\text { groups and other positive }\end{array}$ & 1) & $\begin{array}{l}\text { Create programs that } \\
\text { FIBW feel comfortable } \\
\text { engaging in. }\end{array}$ \\
\hline
\end{tabular}




\begin{tabular}{|c|c|c|c|c|}
\hline $\begin{array}{l}\text { Ability to Build } \\
\text { Social Capital }\end{array}$ & 3) & $\begin{array}{l}\text { social contacts on campus } \\
\text { and in the community. } \\
\text { Ability to recognize they are } \\
\text { gifted in this area and access } \\
\text { to avenues to attach this } \\
\text { skillset to career choice and } \\
\text { financial gain. }\end{array}$ & 3) & $\begin{array}{l}\text { Create social networking } \\
\text { opportunities on campus } \\
\text { for FIBW. } \\
\text { Develop and implement } \\
\text { training for administrators } \\
\text { and faculty on the value of } \\
\text { street experience as a form } \\
\text { of experiential learning. } \\
\text { (Must also address the } \\
\text { stigma of incarceration.) }\end{array}$ \\
\hline 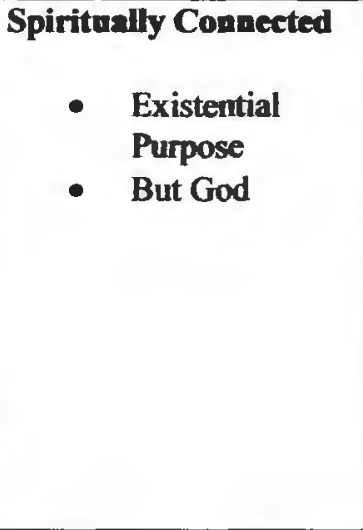 & $\begin{array}{l}\text { 1) } \\
\text { 2) } \\
\text { 3) }\end{array}$ & $\begin{array}{l}\text { To feel as if their lives have } \\
\text { a purpose. } \\
\text { To feel hopeful. } \\
\text { To feel whole just as they } \\
\text { are. }\end{array}$ & 2) & $\begin{array}{l}\text { Develop curricula that } \\
\text { assists FIBW with } \\
\text { determining and moving } \\
\text { towards their life purposes. } \\
\text { Discontinue deficit-based } \\
\text { instruction in regards to the } \\
\text { condition of Black } \\
\text { Americans or at least } \\
\text { provide a balance. } \\
\text { Create culturally affirming } \\
\text { curricula that honors Black } \\
\text { women's strength, beauty, } \\
\text { and contributions. }\end{array}$ \\
\hline
\end{tabular}

\section{Implications for Criminal Justice Field}

It is not enough to call for cultural competence when recommending the engagement in a Gender Responsive approach (Bloom \& Covington, 2003) without gaining an understanding of what competence means in the eyes of all of the women that the approach is supposed to help, including FIBW. Furthermore, without taking the taking the time to figure out what traumatizes FIBW, the call for trauma-informed approaches are mere buzzwords. We are dealing with a criminal justice system that up until recently claimed no desire to stop locking up Black men, women and children. Unless there has been a massive turnover in who works in this field, it is widely unknown how to engage in the loosely recommended trauma-informed, gender responsive and culturally competent approaches for Black women. 
The absence of instructions or detailed definitions on how to carry out the abovementioned strategies sums up to a color-blind approach for all women. Color blindness is a tenet of racism (Bonila-Silva, 2006). It is time for feminist criminologists to gain a better understanding of what it means to be an incarcerated or FIBW. Until this happens, Black women will continue to be overlooked and misunderstood in the criminal justice arena. Without gaining this knowledge, criminology theorists are making uneducated guesses.

This research study points to a new way of assessing the talents and capabilities of formerly incarcerated people. Assessment tools are now being used in the criminal justice field to determine if someone is a high risk for returning to custody. These tests tend to be very racially biased, providing higher scores for Black people than white people (Skeem \& Lowenkamp, 2016). (As an experiment, I answered a risk of offending assessment honestly, and I was found to be high-risk for recidivating even though I had been out of prison 17 years.) The skills learned on the streets are not assessed as assets, and often cognitive behavioral programs are designed to totally erase street behavior. This study implicates that street experience can be valuable and that the skillset necessary to survive on the streets, the hustle, can be transferred in a positive manner in an academic setting.

The criminal justice field typically has reentry programs that are designed based upon the needs of formerly incarcerated people. However, this study suggests that there is a need to find a purpose for living. Without a purpose for living, hopelessness can 
persevere. Some service providers or criminal justice staff may feel that a formerly incarcerated person's basic needs should be met before the ideology of existential purpose is introduced. Waiting for this opportunity to introduce purpose, can be viewed as "meeting clients where they are at". I would beg to differ. Without a purpose for living, the intrinsic ability to move forward in life is unmotivated.

The participants in this study found their existential purpose to be assisting others. This suggests that reentry programs that are seeking to help FIBW should also create efforts to determine their strengths and desires for their lives in an optimal setting, which may be outside of their current reality. In the case of the women in this study, there is a strong desire to give back to their community. Voluntary opportunities to give back to the community should be offered by reentry programs even in the early stages of reentry, which may not be feasible for some. However, it's the suggestion of being enough, needed and capable of helping that can begin the seed planting process of hope. This can assist some FIBW whom have adapted the SBW title in their lives to address their innate yearning to be a part of the answer and not the problem.

The criminal justice field is underutilizing SBW and FIBW. Educated white women that have not done a day in jail have been inserted into the scheme of creating much-needed change in the criminal justice field as experts that advocate for all women. Their "so-called" expertise is being exalted to the point that it is a disservice to FIBW. Gender responsiveness with its vagueness and over usage of buzzwords, such as but not limited to, "trauma-informed" and "cultural competence" without definitions of what this 
means for Black women is no longer acceptable. The time has come for the criminal justice field to develop strategies and approaches that are specifically designed to positively impact the lives of Black women. I have taken on the responsibility of naming and attempting to define this approach, which I referred to in Chapter Two: Literature Review as the Araminta Approach.

\section{The Araminta Approach}

Araminta Ross, whom later changed her name to be Harriet Tubman (Bradford, 1993), was the epitome of a SBW. Black women such as Harriet Tubman are the role models from which the SBW schema seeks to replicate. The emerging characteristics that surfaced in this study among the participants were openly displayed by Harriet Tubman. She had strong self and community advocacy skills, which she displayed by risking her life for her freedom and returning to help others in her community become free. These courageous acts also speak to the matriarchal hierarchy that exists within the Black community, which is oppositional to the notion of patriarchy that is implied within the Gender Responsive, trauma-informed approach.

Although Ms. Tubman suffered through a great deal of trauma, she was hit in the head with metal by an overseer as a child and held captive as an enslaved woman for years afterwards (Bradford, 1993). Her high level of courage and ability to be socially resourceful/hustle outweighed the trauma. I can't think of a more socially resourceful woman. Despite the oppressive forces in life, she still was able to survive in the 
wilderness for days while evading capture, convince others in the community (men, women, and children) to follow her lead, convinced white people to coordinate the escapes with her, and she also engaged in a multitude of other roles, such as a nurse and spy in the Civil War (Bradford, 1993). She had the hustle down pat. Harriet Tubman's persona definitely aligned with the Socially Resourceful/Excellent Hustler emerging characteristic.

The last emerging characteristic Spiritually Connected for this study is in divine alignment with the epitome of who Harriet Tubman was. She believed that her existential purpose in life was to free her people. Freeing her people had to be a burning desire in Harriet Tubman's life that set her spirit on fire order for her to take such risks. One can only imagine the high level of faith and spiritual capital she was privileged to be graced with. On top of taking all of these risks, Ms. Tubman had a disability, which caused her to fall asleep at inopportune times while she was leading other enslaved men, women and children to freedom (Bradford, 1993). Somehow, she never got caught. But God.

The Araminta approach acknowledges the strengths, characteristics, and uniqueness of Black women impacted by the criminal justice system. Below you will find a table that encompasses the needs of FIBW based upon the emerging characteristics of this study and ways that the criminal justice field can fulfill these needs in order to reduce recidivism and facilitate upward mobility. 


\begin{tabular}{|c|c|c|}
\hline Characteristics & FIBW's Needs & The Araminta Approach \\
\hline $\begin{array}{l}\text { Strong Advocacy Skills } \\
\text { - Self } \\
\text { • Community } \\
\text { (Gift of Advocacy) }\end{array}$ & $\begin{array}{l}\text { 1. To feel strong. } \\
\text { 2. To be heard. } \\
\text { 3. To be able to help } \\
\text { others. }\end{array}$ & $\begin{array}{l}\text { 1. Respect for the } \\
\text { matriarchal hierarchy } \\
\text { present in Black } \\
\text { community. } \\
\text { 2. A non-judgmental } \\
\text { listener that is keen to } \\
\text { recognizing and } \\
\text { cultivating strengths. } \\
\text { 3. Design and implement } \\
\text { plans with FIBW to } \\
\text { increase their ability to } \\
\text { take care of their loved } \\
\text { ones and/or give back to } \\
\text { the community. }\end{array}$ \\
\hline $\begin{array}{l}\text { Socially Resourceful/Ercellent } \\
\text { Hustler } \\
\text { - The Hustle } \\
\text { - Ability to Build Social } \\
\text { Capital }\end{array}$ & $\begin{array}{l}\text { 1. Access to various social } \\
\text { opportunities. } \\
\text { 2. Ability to attach this } \\
\text { skillset to career choice } \\
\text { and financial gain. } \\
\text { 3. Multi-tasking is } \\
\text { possible. }\end{array}$ & $\begin{array}{l}\text { 1. Provide social contacts } \\
\text { that lead to upward } \\
\text { mobility. } \\
\text { 2. Recognition that street } \\
\text { experience can be } \\
\text { helpful if utilized } \\
\text { correctly. } \\
\text { 3. Do no limit nor } \\
\text { underestimate the } \\
\text { capabilities of a SBW. } \\
\text { You may have to help a } \\
\text { her look beyond where } \\
\text { she is, but once she } \\
\text { catches on, she can } \\
\text { move mountains. }\end{array}$ \\
\hline $\begin{array}{l}\text { Spiritually Connected } \\
-\quad \text { Existential Purpose } \\
\bullet \quad \text { But God }\end{array}$ & $\begin{array}{l}\text { 1. To feel as if their lives } \\
\text { have a purpose. } \\
\text { 2. To feel hopeful. } \\
\text { 3. To feel whole just as } \\
\text { they are. }\end{array}$ & $\begin{array}{l}\text { 1. Incorporate life purpose } \\
\text { development into } \\
\text { strategies for change. } \\
\text { 2. Do not assume anything } \\
\text { about FIBW'S intellect, } \\
\text { capabilities or value. } \\
\text { 3. Create culturally } \\
\text { affirming criminal } \\
\text { justice programs that } \\
\text { honor Black women's } \\
\text { strength, beauty, } \\
\text { contributions and } \\
\text { uniqueness while also } \\
\text { acknowledging the } \\
\text { struggle (in that order). }\end{array}$ \\
\hline
\end{tabular}


It should be noted that the Araminta Approach doesn't negate the trauma experienced in the lives of FIBW. Quite the contrary, the Araminta Approach celebrates Black women's abilities to move forward despite the trauma, which is evident in the racial historical context of the United States of America.

\section{Implications for Research}

FIBW represent a very diverse identity, which has several intersections. Often when seeking to understand diversity, academic researchers tend to concentrate on physical characteristics, such as race, gender and behavioral patterns without seeking to understand formerly incarcerated individuals intrinsically. Accepting the SBW schema as a normal response to oppressive practices and seeking to gain a better understanding of the schema would be a great start in order to increase the amount of viable empirical academic research literature on FIBW.

The talents of formerly incarcerated people as a whole are underrepresented in the literature. $I$ have had the privilege of living two lives, from the streets to the doctorate. I have had the honor of sitting with extremely intelligent people in my doctorate program and other classrooms. Nevertheless, some of the most insightful, clever and profound statements that I have ever heard in my life were expressed on the streets, in jails and in state prisons. There is a plethora of talents and levels of giftedness that go unrecognized due to assumptions of potential in the criminal justice and academic fields. Researchers, you have written and have access to a vast amount of data on the special educational 
needs of formerly incarcerated people with FIBW buried within it. It is time to research the gifts as well. Research, stigmas, and stereotypes work hand-in-hand. It was research that once declared Black folks to be partially inhuman.

What I would recommend done to further this research is seek to increase the number of FIBW in school to participate in research nationwide. There are several strands of research and practices in fields besides criminal justice and academia that could be furthered by piggybacking this study, including but not limited to the medical, legal, behavioral health, mental health, substance abuse, child welfare, social service and theology fields. I have given what I could to be the springboard for the conversation. What I need now is for courageous researchers to run with the baton. It's been passed. That's all I came to do.

\section{Implications for FIBW in a Collegiate Setting}

I went back to school to get a doctorate degree to kick down academic doors and raise ceilings for FIBW. Nevertheless, I almost left FIBW out of the implications section, trying to fulfill academia's requirements instead of my assignment from God. In order to get back in alignment with my Higher Power, these implications speak directly to FIBW who are pursuing or thinking about pursuing a college education. I may be getting a doctorate degree, but I will never forget where I came from. FIBW are my peers. FIBW have the most control over the changes made in their lives, so I cannot in good conscience take the traditional approach of only speaking to others on their behalf. Therefore, the following portion of this section contains strategies and tips for FIBW to 
leave an educational program whole, fulfilled and graduated, and it speaks directly to them.

First and foremost, I would like to congratulate you for making or pondering upon the decision to receive a higher education. Get it girl! It is not an easy endeavor to insert or imagine yourself in an entirely different setting compared to where you have come from. I have searched my mind to figure out what expertise I have as a former crackhead that is now a doctor. It was by no means easy, but it is a done deal. Therefore, I have the roadmap, and completing this research gave me even more insight to share with you. There are many barriers and obstacles you may have to face with your status as a FIBW that is seeking a higher education. Therefore, I am sharing information that may be helpful with getting you through.

Academia has not been prepared for you, and there is a good chance that you will come into contact with professors and educational administrators, particularly white professors and educational administrators, who may be intimidated by your existence but so what. Their insecurities are not your fault, and their comfort is not your responsibility. Feel free to be yourself and know that you are worthy of taking up space in a higher educational environment. You do not have to fully assimilate to pursue a higher education. Don't quit because they are expecting you to; it is very likely that the faculty and educational administrators have received training that predicts your failure as a student. As a result, they may have no idea about your greatness or power. Speak up for yourself if you have to. Not doing so can lead you to take on extra weight that is not yours to carry. The following is some of the strategies I did to finish a terminal degree in a system that is racially biased, America's K-20 school system. 
Many of us choose careers that are designed to help people. The curricula in some educational programs that I have engaged in, particularly educational programs that are supposed to be centered in social justice, were often extremely depressing and deficitbased when it came to the experiences of Black people. Inn order to get through these types of programs, I found it helpful to supplement the assigned readings with literature that affirmed my greatness. Towards the end of my program, I stopped reading assigned articles that were oppressive for me in depth. Also, it is important to remember that although colleges and universities tend to be very structured environments you are in the "free world", and it is okay to get up and walk out of the classroom and get some air if the curriculum for the day proves to be oppressive or upsetting to you. Just come back once you've had a chance to ground yourself.

Another strategy I have found to be helpful was finding a space to vent regarding the institutionalized, deeply woven white supremacy messages that were subtly delivered to me through the curricula while pursuing a higher education. Find someone you can honestly talk to about your experiences in school that will not judge you for your feelings. Your feelings are valid, and you are not imagining anything. The most important component that enabled me to keep was going was a base of people in the community that counted on me to finish my education and were invested in my growth. The further up I went in my education, the more people in my community counted on me. I've wanted to quit several times, but I couldn't bring myself to let them down. You will find that the more classes you complete, the more people in the community will begin to look up to you.

Once you start completing classes and programs, you may find that you are surprising yourself. This may lead to imposter syndrome, which is a term used for 
students who may feel like they don't belong in an academic setting based upon who they are or their past. Rest assured knowing that it doesn't matter what you have done, it is where you are going that counts. Your past mistakes have now taken on the form of wisdom. Your wisdom combined with a higher education is going to make you a beast out here. Whatever you do, don't quit, and if you are contemplating returning to school rest assured knowing that I kicked the door in and there is no locksmith knowledgeable enough to repair it. You are welcome to come on in.

\section{Limitations}

I somewhat regret that I didn't go deeper with this study. My intent was and still is to give a piggyback ride to other researchers who deem that FIBW's minds, bodies and souls are worthy of attention. There were times when I read the participants of this study's responses and decided to just to keep going instead of calling them and asking more questions. I didn't have the social nor therapeutic support to go deeper because of the amount of pain, trauma, and abuse that was so densely represented in the data and so well-known to me to the point that it was mind and spirit boggling. My close proximity to this research study was somewhat limiting because although I did have the knowledge to go deeper I didn't have the strength. Nevertheless, I went deeper than anything I have read in regards to FIBW in empirical research, so I am satisfied with what I was able to give. 


\section{Conclusion}

The empirical research that is available in regards to incarcerated and/or FIBW and their educational endeavors is non-existent unless it addressed them during their childhood; at least I couldn't find it. It is time for Black girls that were pushed out of schools and into prisons to grow into adulthood in the empirical literature. At this rate, it is next to impossible to develop better mechanisms for academia and/or the criminal justice system to induce much-needed change without proper attention being given. The literature has shown the high level importance of Black women in the community. FIBW are not excluded from this level of importance. As a matter of fact, the life experiences of FIBW can serve as expertise in order to help many others whom have been deemed to be not reachable.

In order to get in the optimal position to create changes in the incarceration disparity of Black Americans, an effort must be coordinated to get to know an extremely important population in the United States of America, incarcerated and/or FIBW Black women. This coordinated effort must be done in a manner that takes intersectionality into consideration and also considers the mindset of incarcerated and/or FIBW. This country, and thus the entire world, has not been the same since the crack epidemic and the mass incarceration of Black women in the 1980's. This research study serves as the starting point to beginning to understand us. Although the incarceration disparity among Black Americans is a topic that can be thoroughly researched, the plight of Black women is not. This lack of the pursuit of understanding in the educational and criminal justice 
empirical literature for FIBW is a form of discrimination that needs to cease. The cease and desist order has now officially been served by the completion of this dissertation. 


\section{References}

Abrams, J. A., Maxwell, M., Pope, M., \& Belgrave, F. Z. (2014). Carrying the world with the grace of a lady and the grit of a warrior: Deepening our understanding of the "Strong Black Woman" schema. Psychology of Women Quarterly, 38(4), 503 518.

Annamma, S. A., Anyon, Y., Joseph, N. M., Farrar, J., Greer, E., Downing, B., \& Simmons, J. (2019). Black girls and school discipline: The complexities of being overrepresented and understudied. Urban Education, 54(2), 211-242.

Alexander, M. (2012). e new Jim Crow: Mass incarceration in the age of colorblindness. NewYork, NY: e New Press.

Andreaou, M., \& Broun, H. H. (1994). And still I rise. Jeffrey Norton Publishers.

Beauboeuf-Lafontant, T. (2007). You have to show strength: An exploration of gender, race, and depression. Gender \& Society, 21(1), 28-51.

Bradford, S. (1993). Harriet, the Moses of her people. New York: For the Author by GR Lockwood \& Son.

Bloom, B., Owen, B. A., \& Covington, S. (2003). Gender-responsive strategies: Research, practice, and guiding principles for women offenders. Washington, DC: National Institute of Corrections. 
Bonilla-Silva, E. (2006). Racism without racists: Color-blind racism and the persistence of racial inequality in the United States. Rowman \& Littlefield Publishers.

Brown, G. W., Gollop, C. J., Goodson, M. G., Green-Powell, P., Hambrick, A., Kingham, L. A., .. \& Vaz, K. M. (1997). Oral narrative research with black women.

Burns Institute. (2015). San Francisco Justice Reinvestment Initiative: Racial and Ethnic Disparities Analysis for the Reentry Council. Summary of Key Findings. Retrieved from http://www.burnsinstitute.org/wpcontent/uploads/2013/12/JRI SF-RED-Analysis-SUMMARY-of-FINDINGS.pdf.

Bush-Baskette, S. R. (1998). The war on drugs as a war against black women. Crime control and women: Feminist implications of criminal justice policy, 113-129.

Clandinin, D. J., \& Connelly, F. M. (2000). Narrative inquiry: Experience and story in qualitative research.

Collins, P. H. (2002). Black feminist thought: Knowledge, consciousness, and the politics of empowerment. Routledge.

Covington, S. S., \& Bloom, B. E. (2007). Gender responsive treatment and services in correctional settings. Women \& Therapy, 29(3-4), 9-33.

Crenshaw, K. (1991). Mapping the margins: Intersectionality, identity politics, and violence against women of color. Stanford Law Review, 43(6), 1241-1299. 
Davey, M., \& Smith, M. (2015). Murder rates rising sharply in many US cities. The New York Times, 1.

Davis, S. M. (2015). The "Strong Black Woman Collective": A developing theoretical framework for understanding collective communication practices of Black women. Women's Studies in Communication, 38(1), 20-35.

Donovan, R. A., \& West, L. M. (2015). Stress and mental health: Moderating role of the strong black woman stereotype. Journal of Black Psychology, 41(4), 384-396.

Essie Justice Group. (2018). Because She's Powerful.

Farmer-Hinton, R. L., Lewis, J. D., Patton, L. D., \& Rivers, I. D. (2013). Dear Mr.

Kozol.... Four African American women scholars and the re-authoring of Savage Inequalities. Teachers College Record, 115(5), 1-38.

Feder, A., Nestler, E. J., \& Charney, D. S. (2009). Psychobiology and molecular genetics of resilience. Nature Reviews Neuroscience, 10(6), 446.

Fullilove, M. T., Lown, E. A., \& Fullilove, R. E. (1992). Crack 'hos and skeezers: Traumatic experiences of women crack users.

Ginwright, S. (2015). Hope and healing in urban education: How urban activist and teachers are reclaiming matter of the heart. Routledge. 
Hager, E. (2017). A mass incarceration mystery. The Washington Post, p. The Washington Post, Dec 15, 2017.

Hambrick, A. (1994). Biographies of black female scientists and inventors. An interdisciplinary middle school curriculum guide:" What Shall I Tell my Children Who are Black?". Unpublished doctoral dissertation, University of Massachusetts Amherst.

Harlow, C. W. (2003). Education and Correctional Populations. Bureau of Justice Statistics Special Report.

Heidermann, G., Cederbaum, J., \& Martinez, S. (2016a). Beyond recidivism. Affilia: Journal of Women and Social Work, 31(1), 24-40.

Heidemann, G., Cederbaum, J., Martinez, S., \& LeBel, T. (2016b). Wounded healers: How formerly incarcerated women help themselves by helping others. Punishment \& Society, 18(1), 3-26.

Irby, D., \& Mawhinney, L. (2014). Strategy development for urban dropout prevention: Partnering with formerly incarcerated adult noncompleters. Preventing School Failure, 58(2), 110-119.

Joseph, N. M., Viesca, K. M., \& Bianco, M. (2016). Black Female Adolescents and Racism in Schools: Experiences in a Colorblind Society. The High School Journal, 100(1), 4-25. 
Jones, M. (2013). From Crack to College and Vice Versa.

Farmer-Hinton, R. L., Lewis, J. D., Patton, L. D., \& Rivers, I. D. (2013). Dear Mr.

Kozol.... Four African American women scholars and the re-authoring of Savage Inequalities. Teachers College Record, 115(5), 1-38.

Lal, S., Suto, M., \& Ungar, M. (2012). Examining the potential of combining the methods of grounded theory and narrative inquiry: A comparative analysis. The Qualitative Report, 17(21), 1.

Lashley, M. (2014). Self-Perceptions of Black Single Mothers Attending College. Comprehensive Psychology, 3, Comprehensive Psychology, 01 January 2014, Vol.3.

Lawrence-Lightfoot, S. (2005). Reflections on Portraiture: A Dialogue Between Art and Science. Qualitative Inquiry, 11(1), 3-15.

Leverentz, A. (2011). Being a good daughter and sister. Feminist Criminology, 6(4), 239267.

Lewis, J. A., Mendenhall, R, Harwood, S. A., \& Huntt, M. B. (2013). Coping with gendered racial microaggressions among Black women college students. Journal of African American Studies, 17(1), 51-73. 
Males M. (2015). San Francisco's Disproportionate Arrest of African American Women Persists. http://www.cici.org/uploads/cici/documents/disproportionate arrests in san fran cisco.pdf.

Mallett, C.A. (2016). The school to prison pipeline: A critical review of the punitive paradigm shift. Child and adolescent social work journal, 33(1), 15-24.

Meier, D. R., \& Stremmel, A. J. (2010). Reflection through narrative: The power of narrative inquiry in early childhood teacher education. Journal of Early Childhood Teacher Education, 31(3), 249-257.

Morris, M. (2016). Pushout: The criminalization of Black girls in schools. New Press, The.

Morris, A. (1996). The Black Church in the Civil Rights Movement. Disruptive religion: The force of faith in social-movement activism, 29-46.

Narcotics Anonymous. (1984). Narcotics Anonymous: Approved literature: 12 steps and 12 traditions. (3rd ed., new \& rev. ed.). Van Nuys, CA: World Service Office.

Perkins, A. E. (1922). Negro spirituals from the far south. The Journal of American Folklore, 35(137), 223-249. 
Rose, K., \& Rose, C. (2014). Enrolling in college while in prison: Factors that promote male and female prisoners to participate. Journal of Correctional Education, 65(2), 20-39. Retrieved from http://search.proquest.com/docview/1538272337?accountid=13802.

Skeem, J. L., \& Lowenkamp, C. T. (2016). Risk, race, and recidivism: Predictive bias and disparate impact. Criminology, 54(4), 680-712.

Solórzano, D. G., \& Yosso, T. J. (2002). Critical race methodology: Counter-storytelling as an analytical framework for education research. Qualitative inquiry, 8(1), 2344.

Yosso*, T. J. (2005). Whose culture has capital? A critical race theory discussion of community cultural wealth. Race ethnicity and education, 8(1), 69-91.

Staton-Tindall, M., Duvall, J., Stevens-Watkins, D., \& Oser, C. B. (2013). The roles of spirituality in the relationship between traumatic life events, mental health, and drug use among African American women from one southern state. Substance use \& misuse, 48(12), 1246-1257.

Strayhorn, T., Johnson, R., \& Barrett, B. (2013). Investigating the College Adjustment and Transition Experiences of Formerly Incarcerated Black Male Collegians at Predominantly White Institutions. Spectrum: A Journal on Black Men, 2(1), 7398. 
Staton-Tindall, M., Duvall, J., Stevens-Watkins, D., \& Oser, C. B. (2013). The roles of spirituality in the relationship between traumatic life events, mental health, and drug use among African American women from one southern state. Substance use \& misuse, 48(12), 1246-1257.

Vacca, J. (2006). Educated prisoners are less likely to return to prison. Journal of Correctional Education, 55(4), 297-305.

Veysey, B., Christian, J., \& Martinez, D. J. (Eds.). (2013). How offenders transform their lives. Routledge.

Watson, N. N., \& Hunter, C. D. (2016). "I had to be strong" tensions in the strong black woman schema. Journal of Black Psychology, 42(5), 424-452.

Williams, C. (1990). Crack is genocide, 1990s style. New York Times.

Wun, C. (2016). Against Captivity: Black Girls and School Discipline Policies in the Afterlife of Slavery. Educational Policy, 30.1 (2016): 171-196.

Yosso, T. J. (2005). Whose culture has capital? A critical race theory discussion of community cultural wealth. Race ethnicity and education, 8(1), 69-91. 


\section{Appendix A}

\section{DEMOGRAPHIC SURVEY}

STUDY ID\#

\section{PERSONAL INFORMATION}

Last Name

Age $\overline{\text { Middle Initial }}$

First Name
Street Address

Home Phone
City

Cell Phone

\section{ZIP}

Email

Contact Person (In case you move or something changes)

Name

Relationship

Phone\#

\section{PROGRAM ELIGIBILITY}

Please circle the answer for the following questions:

1. Do you identify as a Black or African American woman?

Yes

No

2. Are you formerly incarcerated?

Yes

No

2a) If so, what is an estimate of the total amount of time you have been incarcerated in your lifetime?

3. Are you attending college or pursuing a high school diploma or GED? Yes

4. Have you finished an educational certificate or diploma/degree program after release from jail or prison?

5. What is the highest level of education you have completed? 

A) Some high school
B) High school/GED completion
C) Some college
D) Certificate program
E) Associate degree
F) Bachelor degree
G) Master degree

6. If you are in school right now, what is your educational goal?

6a. If you completed your educational goal, what was your degree or certificate in? 


\section{Appendix B}

\section{Writing Prompts}

Week 1 - When did your life take a turn and lead you down the path to incarceration?

What happened? What was the single most important moment that made you realize you had to change your life? What was the first step you took? PLEASE BE SPECIFIC AND PROVIDE EXAMPLES IF POSSIBLE.

Week 2 - What made you gravitate towards going back to school as part of your process of changing? Did you have any fears or any apprehension when you first returned to school? If so, why were you feeling this way, and how did you overcome those feelings? If not, what made you feel confident? PLEASE BE SPECIFIC AND PROVIDE EXAMPLES IF POSSIBLE.

Week 3 - What is a strong Black woman? What is she required to do? Would you consider yourself a strong Black woman? If yes, please explain? How does this title affect you negatively? How does this title affect you positively? If you don't consider yourself a strong Black woman, please explain. PLEASE BE SPECIFIC AND PROVIDE EXAMPLES IF POSSIBLE.

Week 4 -How did you develop the skills to become academically successful? Who or what helped you along the way? How did you go about getting what you needed to be 
successful? What made you keep going as far as you have gone with your education? PLEASE BE SPECIFIC AND PROVIDE EXAMPLES IF POSSIBLE.

Week 5 - As a Black woman pursuing a higher education, have you experienced any racial, class, or gender discrimination from your instructors or other college or university staff members or students? If so, how did you cope with the situation or situations? Can you write about a specific situation that you experienced racial, class and gender discrimination and how you dealt with it? PLEASE BE SPECIFIC AND PROVIDE EXAMPLES IF POSSIBLE.

Week 6 - There are many women who have had similar life experiences as yourself and were unable to make the changes you have in their lives. Some of them are still engaged in the cycle of incarceration, drug addiction, and many are deceased. Previously we have asked you who or what has helped you become the woman you are today. However, please think deeply and try to embrace what is it about YOU (i.e. your personality, what you believe in, etc.) that helped you escape these outcomes in your life? PLEASE BE SPECIFIC AND PROVIDE EXAMPLES IF POSSIBLE. 